\title{
Mycosphere Essays 15. Ganoderma lucidum - are the beneficial medical properties substantiated?
}

\author{
Hapuarachchi KK ${ }^{1,2,3}$, Wen TC ${ }^{1}$, Jeewon $\mathrm{R}^{4}$, Wu XL ${ }^{5}$ and Kang $\mathrm{JC}^{1}$ \\ ${ }^{I}$ The Engineering Research Center of Southwest Bio-Pharmaceutical Resource Ministry of Education, Guizhou \\ University, Guiyang 550025, Guizhou Province, China \\ ${ }^{2}$ Center of Excellence in Fungal Research, Mae Fah Luang University, Chiang Rai 57100, Thailand \\ ${ }^{3}$ School of Science, Mae Fah Luang University, Chiang Rai 57100, Thailand \\ ${ }^{4}$ Department of Health Sciences, Faculty of Science, University of Mauritius, Mauritius, 80837 \\ ${ }^{5}$ Guizhou Academy of Sciences, Guiyang, 550009, Guizhou Province, China
}

Hapuarachchi KK, Wen TC, Jeewon R, Wu XL, Kang JC. 2016 - Mycosphere Essays 15. Ganoderma lucidum - are the beneficial medical properties substantiated?. Mycosphere 7(6), 687715, Doi 10.5943/mycosphere/7/6/1

\begin{abstract}
Ganoderma lucidum, commonly treated as Lingzhi mushroom, is a traditional Chinese medicine which has been widely used over two millennia in Asian countries for maintaining vivacity and longevity. Numerous publications can be found reporting that G. lucidum may possess various beneficial medical properties and contributes to a variety of biological actions by primary metabolites, such as polysaccharides, proteins and triterpenes. Although G. lucidum still remains as a popular agent in commercial products, there is a lack of scientific study on the safety and effectiveness of $G$. lucidum in humans. There have been some reports of human trials using $G$. lucidum as a direct control agent for various diseases including arthritis, asthma, diabetes, gastritis, hepatitis, hypertension and neurasthenia, but scientific evidence is still inconclusive. In this paper, we discuss various aspects pertaining to the beneficial medical properties of G. lucidum (excluding anti-cancer activities). In particular, we have addressed some of the loopholes in previous studies that support G. lucidum and its secondary metabolites as effective agents to treat various human diseases. Most of the clinical trials were successful with G. lucidum preparation, however factors like small sample size, lack of a placebo control group, lack of information regarding long term treatment of the drug, age, patient's gender and side effects, standard method of extraction of $G$. lucidum, standard dosage, and number of patients treated undermine the validity of the results. Hence, G. lucidum can be used as a therapeutic drug when more direct and supportive scientific evidence are available in near future.
\end{abstract}

Key words - clinical evidence - Lingzhi - medicinal mushroom - secondary metabolites

\section{Introduction}

Ganoderma lucidum is a popular medicinal mushroom and widely used to promote health and longevity for over two millennia (Zhao et al. 2015). It is known as 'Lingzhi' and was first indexed in Shen Nong's Materia Medica (206 BC-8 AD) as a longevity promoting and tonic herb of the non-toxic superior class (Zhu et al. 2007). Ganoderma lucidum (Curt: Fr.) Karst. belongs to phylum Basidiomycota, order Polyporales and family Ganodermataceae (Index Fungorum 2016, http://www.indexfungorum.org/). Liu (1974) compiled a monograph of Traditional Chinese 
Medicinal Fungi, and he assigned G. lucidum to "Lingzhi" in his book. Since then, G. lucidum has been accepted as the scientific binomial of "Lingzhi" in many reports on Chinese edible and medicinal mushrooms (Ying et al. 1987, Mao 1998, Dai et al. 2009, Cao et al. 2012, Richter et al. 2015). The Chinese "Lingzhi" has continuously been referred to the name G. lucidum in monograph of Ganodermataceae in China (Hapuarachchi et al. 2015, Zhou et al. 2015). Ganoderma lucidum is mainly distributed in East Asia, including China, Japan and the Korean peninsula, and is listed in the American Herbal Pharmacopoeia, Chinese Pharmacopoeia and Therapeutic Compendium (Wu et al. 2013). The annual sale of products is estimated to be more than US\$ 2.5 billion in Asian countries since it is among the most sought medicinal mushrooms in the world market (Li et al. 2013). Numerous studies and research have demonstrated that a vast number of pharmacological and bioactive compounds can be extracted from G. lucidum (Paterson 2006). Chemical investigations of the fruiting body, mycelia, and spores revealed that they contain approximately 400 compounds, including triterpenes, polysaccharides, sterols, and peptides (Zhao et al. 2015). This mushroom contains polysaccharides and triterpenes as the two major groups, then phenols, steroids, amino acids, lignin, mycins, vitamins, nucleosides, and nucleotides (Mizuno et al. 1995, Zhu et al. 1999, Mizuno et al. 2003, Gao et al. 2004a, b). Hence, the fruiting bodies of $G$. lucidum species have gained wide popular use as dietary supplements in China, Japan, North America and the other regions of the world. However, in recent times particularly in Western countries, there has been an increased interest to use it as dietary supplements and remedies along or in place of allopathic medicine (Yuen \& Gohel 2005). Ganoderma lucidum has been used as a functional food to prevent and treat many immunological diseases, such as anorexia, arthritis, asthma, bronchitis, cardiovascular problems, constipation, diabetes, dysmenorrhea, gastritis, hemorrhoids, hepatitis, hypercholesterolemia, hypertension, insomnia, lupus erythematosis, migraine, nephritis, neurasthenia, neoplasia and tumorigenesis (Liu et al. 2002, Tang et al. 2005, Paterson 2006, Wang et al. 2012, Hapuarachchi et al. 2016). This fungus has been extensively studied as an anti-cancer agent, and it has been reported to have anti-oxidant activities (Yen \& Wu 1999, Mau et al. 2002), cardio protective effects (Sudheesh et al. 2013) and anti-diabetic potency (Teng et al. 2011). Produced from different parts of its fruit body, mycelia or spores are widely accepted as remedies, which can help enhance the body's immune system and improve metabolic functions. Furthermore, it is commercially cultivated and a diversity of remedies are available in the forms of tea, powder, extracts, dietary supplements, spore products, drinks, syrups, tooth pastes, soaps and lotions (Chang \& Buswell 1999, Lai et al. 2004, Zhou et al. 2007, Singh et al. 2013).

\section{Anti-oxidant activity}

Mohan et al. (2015) demonstrated oxidation is a fundamental biological process of many living organisms for the production of energy and the uncontrolled production of oxygen-derived free radicals is hostile and damaging to cells. Moreover, they were believed to cause diseases, including, aging, arthritis, atherosclerosis, Alzheimer's diseases, cancer, carcinogenesis, genetic damage, heart diseases, inflammation, Parkinson's, tissue loosening and further it promotes tumor invasion and metastasis. Nowadays many synthetic antioxidants are used to reduce oxidation damage of cells; however, researchers found that synthetic antioxidants can result in health hazards such as liver damage and carcinogenesis (Singh \& Rajini 2004, Yuan et al. 2008). Hence, it is necessary to develop efficient natural antioxidants to protect body cells from free radicals and reduce the risk of side effects and various other diseases. Triterpenes, Polysaccharides, polysaccharide-peptide complex and phenolic components of G. lucidum have been proposed to be responsible for the antioxidant effect (Kana et al. 2015, Mehta 2014). Ganoderma lucidum antioxidants were found to be absorbed quickly after ingestion, resulting in an increase in the plasma total antioxidant activity of human subjects (Wachtel-Galor et al. 2004). The antioxidant activities of the polysaccharides extracted from G. lucidum still remains poorly unknown (Kana et al. 2015). Its polysaccharides exhibited a relatively high level of radical scavenging activity with lower $\mathrm{IC}_{50}$ (Half maximal inhibitory concentration) values and a higher antioxidant activity since G. lucidum polysaccharides (GLP) were rich in antioxidant components, such as proteins, amino 
acids, peptides, phytosterols, ascorbic acid and microelements (Mohan et al. 2015). Polysaccharides of G. lucidum decrease the production of oxygen free radicals and antagonize the respiratory burst in order to help anti-aging process. Its polysaccharides also exhibit reducing power and chelating effects on Ferrous $\left(\mathrm{Fe}^{2+}\right.$ ) ions (Liu et al. 2010, Kozarski et al. 2012). A homo-polysaccharide composed of mannose has antioxidant activity under in vitro and in vivo conditions and it has promising free radicals $\left(\mathrm{O}_{2} ; \mathrm{HO}\right.$ and DPPH) scavenging ability and further it increases the activity of antioxidant enzymes (Ferreira et al. 2014). Ganoderma lucidum peptidoglycan prevent induced necrosis of macrophages by t-butyl hydroperoxid ( $\mathrm{t}-\mathrm{BOOH})$ in order to protect the mitochondria, endoplasmic reticulum and macrophage microvilli from oxidative damage and malfunction (Giavasis 2014). Ganoderma lucidum glucans have been reported to act as free radical scavengers in food and inhibit lipid peroxidation simultaneously stimulating interferone synthesis in human blood cells (Giavasis 2014). The radicals scavenging activity increases the activity of antioxidant enzymes: superoxide dismutase (SOD) which catalyzes dismutation of superoxide anion to hydrogen peroxide; catalase (CAT) which detoxifies hydrogen peroxide and converts lipid hydroperoxides to nontoxic substances; and glutathione peroxidase (GSH-Px) maintains the levels of reduced glutathione (GSH) (Ferreira et al. 2014). The superoxide anion radical scavenging effects and Hydroxyl radical scavenging activities of the G. lucidum polysaccharides were high at increased concentrations of GLP (Mohan et al. 2015). Glycopeptide isolated from G. lucidum showed an antioxidant activity against the injury of macrophages induced by ROS (You \& Lin 2002). Jia et al. (2009) showed the antioxidant activity of GLP on streptozotocin (STZ)-a diabetic rat. The results revealed that it increased non-enzymatic and enzymatic antioxidants, serum insulin level, and also reduced the lipid peroxidation. GLP80, exhibited promising antioxidant activities (Kana et al. 2015). A glycopeptide isolated from G. lucidum, composed of 17 amino acids and rhamnose, xylose, fructose, galactose, mannose and glucose as sugars had antioxidant activity by reducing ROS formation, MDA (Malondialdehyde) levels and increasing the activity of manganese superoxide dismutase in rat cerebral cortical neuronal cultures exposed to hypoxia (Zhao et al. 2004). This glycopeptide also showed antioxidant activity (free radicals scavenging ability) by protecting against alloxan induced pancreatic islets damage under in vitro and in vivo conditions (Zhang et al. 2003). Methanol extracts of G. lucidum were reported to prevent kidney damage through restoration of the renal antioxidant defense system inducing the anti-cancer drug cisplatin (Sheena et al. 2003). Mohan et al. (2015) concluded that no direct link has been established between the antioxidant properties of G. lucidum and its immunomodulatory and anticancer effects, and whether it acts as an antioxidant or pro-oxidant. However, Nithya et al. (2015) reported that $G$. lucidum has potential activity against mammary carcinoma probably by its antioxidant and enzymatic activity with the strong evidence by decreased enzymatic and non-enzymatic reaction such as superoxide dismutase, catalase, Glutathione peroxidase, reduced glutathione, lipid peroxidation, Vitamin $\mathrm{C}$, vitamin E decreased mitochondrial and glycolytic enzymes. Flavonoids and tannins in the G. lucidum extract (GWater-Alc) indicate antioxidant activity. The anti-oxidant activity protects cell damage caused by oxygen reactive species involved in the inflammation pathology (Fidelis et al. 2014). The hydroethanolic solution of G. lucidum (GWater-Alc) showed an anti-inflammatory activity very significantly (Wadt et al. 2015).

\section{Anti- Microbial Activity}

Ganoderma lucidum have been demonstrated to have antimicrobial activities against several bacterial, fungal and viral pathogens (Gao et al. 2003, Keypour et al. 2008, Jonathan \& Awotona 2010). Mehta (2014) revealed Polysaccharides are the major antimicrobial compounds in $G$. lucidum. Many researchers (Hobbs 1995, Wasser \& Weis 1997, Stamets 2000, Suay et al. 2000, Gao et al. 2003) found that G. lucidum contain antibacterial constituents that are able to inhibit Gram-positive and Gram-negative bacteria. Yoon et al. (1994) discovered G. lucidum water extracts was more effective than antibiotics against pathogenic bacterial species such as Escherichia coli, Micrococcus luteus, Staphylococcus aureus, Bacillus cereus, Proteus vulgaris, and Salmonella typhimurium. Oei (2003) reported that G. lucidum could be used as feed 
supplement to resist microbial infections and boost immune system in human beings. Jonathan \& Awotona (2010) revealed, the crude and the purified extracts of G. lucidum has significant antibacterial activities in vitro against E. coli, Pseudomonas aeruginosa, Proteus mirabilis, Klebseilla pneumonia, S. aureus, B. cereus and Actinomyces sp. Ganoderma lucidum extracts showed a higher activity against $S$. aureus and B. cereus than the antibiotics ampicillin and streptomycin (Heleno et al. 2013). The C-3 epimer of Ganoderic acid T (22S, 24E)-3 $\alpha, 15 \alpha, 22-$ triacetoxy-5 $\alpha$-lanosta-7, 9, (11), 24-trien-26-oic acid compound also exhibited significant antimycobacterial activity against Mycobacterium tuberculosis H37Ra (Isaka et al. 2013). Ganoderma lucidum spore powder could be used against Prevotella intermedia from sub gingival plaque in conjunction with conventional therapy in periodontal disease (Nayak et al. 2015). Both crude and the purified extracts of G. lucidum showed antifungal efficacy against Aspergillus flavus, A. fumigatus, A. niger, A. tamarri, Candida albicans, Fusarium oxyporum, Malassezia sloffiae, M. sympodialis, Mucor indicus, Pache dermatitis, Penicillium oxalium and $P$. chrysogenum (Boh et al. 2013, Sridhar et al. 2011). Wang \& Ng (2006) isolated an antifungal protein called Ganodermin from G. lucidum fruiting bodies. Ganodermin inhibited mycelial growth of Botrytis cinerea, F. oxysporum and Physalospora piricola (Zhang et al. 2011). The volatile organic compounds identified from hydrodistillates and solvent extracts of the fruiting bodies of G. lucidum were responsible for cytotoxicity and antimicrobial activity (Ziegenbein et al. 2006). Ganoderma lucidum extracts inhibited the development of Helicobacter pylori, which is responsible for the formation of gastric ulcers and gastric cancer (Suay et al. 2000). Further, antifungal activity against Trichoderma viride exceeded that of the standards of fungicides bifonazole and ketoconazole. Methanol extract of $G$. lucidum showed antimicrobial activity against B. cereus, Enterobacter aerogenes, E. coli, S. aureus, and P. aeruginosa (Shah et al. 2014).

Taylor \& Reide (1998) revealed that only two classes of drugs are currently used to treat HIV (anti-human immunodeficiency virus) infection in western medicine and one class is protease inhibitors. They interfere with HIV replication by inhibiting post-translational processing of viral precursor polypeptides. Ganoderma lucidum has anti HIV-1 protease activity and hence it could be used to treat HIV infection via the same mechanism. Several triterpenoid compounds of G. lucidum possess anti-HIV-1 activity, including Ganoderic acid A which exhibited inhibitory activity against HIV-1 proteases (El-Mekkawy et al. 1998). Wang \& Ng (2006) demonstrated that G. lucidum also contained laccases which might inhibit HIV-1 reverse transcriptase. Some compounds such as Ganodermanondiol, Lucidumol B, Ganodermanontriol, Ganoderic acid B and Ganolucidic acid A showed significant HIV-1 protease activity. Eo et al. (2000) found that Ganoderic acids had antiviral activity against HIV and Epstein-Barr virus. Giavasis (2014) reported, Lentinan, an acidic proteoglucan from $G$. lucidum has been used as anti-HIV drug. It increased host resistance to HIV virus, and limiting the toxicity of conventional anti-HIV drugs. Polysaccharide fractions extracted from G. lucidum are shown to exhibit activity against herpes simplex virus-1 (HSV-1) and herpes simplex virus-2 (HSV-2) (Oh et al. 2000, Liu et al. 2004, Pillai et al. 2010). Ganodermadiol exhibited activity against herpes simplex virus type 1 (Bisko \& Mitropolskaya 1999). A marked synergistic effect was reported with protein-bound polysaccharide (PBP) from G. lucidum, when used in tissue culture in conjunction with anti-herpetic agents, acyclovir or vidarabine, and with interferon alpha (IFN- $\alpha)$ (Kim et al. 2000, Oh et al. 2000).

Malaria, a human parasite causing about 2.5 million deaths each year, is an infectious disease caused by the genus Plasmodium (Mendis et al. 2000). Very few drugs those are active against Malaria up to now and any direct therapeutic agents were still not available (Wells et al. 2009, Gamo et al. 2010, Anthony et al. 2012, Kulangara et al. 2012). The new lanostanes Ganoderic acids TR and S, Ganoderic aldehyde TR and Ganodermanondiol extracted from $G$. lucidum by Adams et al. (2010), exhibited moderate in vitro antiplasmodial activity. Water soluble substances like GLhw (high molecular weight components isolated from water soluble substances of G. lucidum) and GLlw (low molecular weight components isolated from water soluble substances of G. lucidum) and methanol soluble GLMe-1-8 isolated from fruit bodies inhibited replication of influenza A virus. Polysaccharides showed a direct action towards hepatitis B virus 
(HBV) by inhibiting DNA polymerase. Water extract from G. lucidum inhibited proliferation of HPV transformed cells (Hernandez-Marquez et al. 2014). Zhang et al. (2014) evaluated the antiviral activities of two G. lucidum triterpenoids (GLTs), Lanosta-7, 9(11), 24-trien-3-one, 15; 26-dihydroxy (GLTA) and Ganoderic acid Y (GLTB), against EV71 (Enterovirus 71) infection. These two natural compounds display significant anti-EV71 activities without cytotoxicity in human rhabdomyosarcoma (RD) cells as evaluated by 3-(4, 5-Dimethylthiazol-2-yl)-2, 5diphenyltetrazolium bromide (MTT) cell proliferation assay. The results suggested that GLTA and GLTB prevent EV71 infection through interaction with the viral particle to block the adsorption of virus to the cells. In addition, the interactions between EV71 virion and the compounds were predicated by computer molecular docking, which illustrated that GLTA and GLTB may bind to the viral capsid protein at a hydrophobic pocket (F site), and thus may block uncoating of EV71. Moreover, they demonstrated that GLTA and GLTB significantly inhibit the replication of the viral RNA (vRNA) of EV71 replication through blocking EV71 uncoating.

\section{Anti-diabetic effects}

Polysaccharides, proteoglycans, Proteins and Triterpenoids from Ganoderma lucidum are responsible to have hypoglycemic effects (Ma et al. 2015). Polysaccharides of G. lucidum showed hypoglycemic effects by increasing plasma insulin levels and decreasing plasma sugar levels in mice (Hikino et al. 1985, 1989). These polysaccharides enhanced the activities of hepatic glucokinase, phosphofructokinase, and glucose-6-phosphate dehydrogenase and inhibit glycogen synthetase activity. Further they decreased the hepatic glucose production and prevent hyperglycemia (Agius 2007, McCormack et al. 2001). Zhang et al. (2003) found that G. lucidum polysaccharides protect pancreatic cells against alloxan induced damage by inhibiting $\mathrm{NF}-\mathrm{K} \mathrm{B}$ activity. He et al. (2005) reported the main cause of mortality and morbidity in patient with diabetes was endothelial cell apoptosis which is associated with cardiovascular problems. Laboratory tests revealed that $G$. lucidum consumption can provide beneficial effects in treating type 2 diabetes mellitus (T2DM) by lowering the serum glucose levels through the suppression of the hepatic PEPCK gene (Phosphoenolpyruvate carboxykinase) expression (Seto et al. 2009). Oliver-Krasinski et al. (2009) showed G. lucidum polysaccharides with low molecular weights can cause hypoglycemic effects, protect pancreatic cells from cell death, and promote cell regeneration by up regulating Bcl-2(B-cell lymphoma 2), an anti- apoptosis protein and PDX-1 (Pancreatic and duodenal homeobox 1). Ganoderma lucidum polysaccharides can increase body weight, blood glucose levels and serum insulin levels and decrease blood Cholesterol levels (Li et al. 2011). Studies have demonstrated that these Polysaccharides can decrease the mRNA level of key enzymes in glycogenolysis and gluconeogenesis such as hepatic glycogenphosphorylase, fructose1, 6-bisphosphatase, phosphoenolpyruvate carboxykinase and glucose-6-phosphatase. Further, these polysaccharides decreased serum glucose levels and abnormal serum insulin levels in STZ/high fat diet-induced type II diabetic mice. Zheng et al. (2012) reported inducible nitric oxide synthases and caspase-3 were down-regulated in STZ-induced diabetic rats, which induced apoptosis. Ganoderma lucidum polysaccharides can stimulate wound healing and increase wound healing capacity in STZ-induced diabetic mice (Tie et al. 2012, Cheng et al. 2013). These polysaccharides enable decreasing mitochondria oxidative stress, inhibiting activity and nitration of manganese superoxide dismutase (Mn SOD), suppressing glutathione peroxidase (GPx) activity, decreasing redox enzyme p66Shc expression and phosphorylation (Ma et al. 2015).

Ganoderma lucidum triterpenoids inhibit aldose reductase and $\alpha$-glycosidase enzymes and aldose reductase converts glucose into sorbitol which is a key step in Polylol pathway (Fatmawati et al. 2010a, b, 2011a, b, 2013) however, the accumulation of sorbitol can cause diabetic complications such as neuropathy, cataracts, and retinopathy (Bhatnagar \& Srivastava 1992, Schemmel et al. 2010). Extracts of G. lucidum contain ganoderic acid C2, ganoderenic acid A and ganoderic acid Df which has aldose reductase enzyme inhibitory activity (Fatmawati et al. 2009). $\alpha$ Glycosidase converts disaccharides and oligosaccharides to glucose in the small intestine epithelium and hence inhibition of $\alpha$-glycosidase by Ganoderic acids lead to relieve hyperglycemia 
(Fatmawati et al. 2011a). Ling Zhi-8 (LZ-8) is a protein found in G. lucidum and it shows immunomodulatory and anti-type I diabetes activities (Kino et al. 1989, 1990). LZ-8 has mitogen activity and it can lower the plasma Glucose concentration, further LZ-8 decreased lymphocyte infiltration and increased antibody detection of insulin in beta cells in NOD (Non-obese diabetic) mice (Ma et al. 2015). Ma et al. (2015) concluded that LZ-8 responsible for immunomodulatory activity to inhibit diabetes by adjusting subsets of immune cells. Teng et al. (2011) reported an acidic proteoglycan FYGL (Fudan-Yueyang-G.lucidum) extracted from G. lucidum can inhibit PTP1B (Protein tyrosine phosphatase 1B) in vitro. PTP1B helps in negative regulation of insulin receptor signaling and decreases expression of insulin receptor $\beta$ subunit (Combs 2010, Feldhammer et al. 2013). FYGL has dose dependent hypoglycemic and hypolipidemic effects and further it increases blood insulin levels and inhibits PTP1B activity and decreases PTP1B protein expression in skeletal muscle cells (Teng et al. 2012). Pan et al. (2013) revealed FYGL in skeletal muscle cells and adipocyte cells induce glucose transporter 4 (GLUT4) protein expressions in diabetic $(\mathrm{db} / \mathrm{db})$ mice. FYGL increases the use of glucose in muscle cells and adipocytes and lower hepatic glucose output into the blood to decrease blood glucose levels. Further, FYGL has effects on pancreatic islet regeneration and antioxidant activity in $\mathrm{db} / \mathrm{db}$ mice. Pan et al. (2014) found a highly water-soluble proteoglycan FYGL-n, a hyper branched heteropolysaccharide can be isolated from G. lucidum. Hence FYGL-n may play special roles for its bioactivities in PTP1B inhibition and antihyperglycemic potency. Ma et al. (2015) reported FYGL was sensitive to glycosidase, and hypothesized glycan was released in the stomach or small intestine and the glycan dissociated protein motifs and interact with PTP1B. Wang et al. (2015) revealed that GLSP (G. lucidum spore powder) consumption reduced the blood glucose levels by promoting glycogen synthesis and inhibiting gluconeogenesis. GLSP treatment was also associated with the improvement of blood lipid compositions through the regulation of cholesterol homeostasis in the type 2 diabetic rats.

\section{Cardiovascular problems}

Sudheesh et al. (2013) reported that administration of Ganoderma lucidum and $\alpha$ Tocopherol significantly protected mitochondria by preventing the decline of antioxidant status and mitochondrial membrane potential $(\Delta \Psi \mathrm{mt})$ or by directly scavenging the free radicals in order to reduce cardiac toxicity and mitochondrial dysfunction. Gao et al. (2004) demonstrated Ganopoly treatment ( $G$. lucidum polysaccharides) was well tolerated and active in patients with Coronary Heart Diseases. It significantly decreased the percentage of abnormal ECG, blood pressure and serum cholesterol level, further it lasts the cholesterol level unchanged of the patients. Lai et al. (2006) suggested G. lucidum significantly reduced oxidative damage and apoptosis in PTEC (Proximal tubular epithelial cells) induced by HSA (Human serum albumin). The differential reduction of IL-8 (tubular secretion of interleukin) or sICAM-1 (soluble intercellular adhesion molecules) released from HSA-activated PTEC by different components of the LZ (G. lucidum extract) proves that components of G. lucidum with different molecular weights could have different roles and operate different mechanisms in preventing HSA-induced PTEC damage.

\section{Other beneficial properties of Ganoderma lucidum}

The compounds cyclooctasulfur and oleic acid isolated from Ganoderma lucidum (culture broth) inhibit releasing histamine which is an important activity for treatment of inflammation, allergies, and anaphtlactic shock (Tasaka et al. 1988a, 1988b). The alkaloids, choline and betaine were isolated from the spores of G. lucidum. Vitamins (including $\beta$-carotene) and essential elements have been isolated (Paterson 2006). Elemental analysis of G. lucidum fruit bodies revealed Phosphorus, Silica, Sulphur, Potassium, Calcium, and Magnesium to be their main mineral components and Iron, Sodium, zinc, Copper, Manganese, Strontium, Lead, Cadmium, and Mercury were also detected in traces (Chen et al. 1998). It also contains organic Germanium (Chiu et al. 2000), Protein (Chang \& Buswell 1996, Mau et al. 2001), lectins (Kawagishi et al. 1997, Thakur et al. 2007), enzymes such as metallo-protease, nucleosides and nucleotides such as adenosine and guanosine (Wasser et al. 2005, Paterson 2006). Ganoderma lucidum could be 
considered as sources of preservatives of food industry (Kana et al. 2015). Lower urinary tract symptoms in men can be treated with G. lucidum ethanol extract effectively (Noguchi et al. 2008a, b). Further, G. lucidum extracts suppress prostatic growth partly by its ability to inhibit $5 \alpha$ reductase, which is over expressed in Benign Prostatic Hyperplasia (BPH) tissues (Liu et al. 2007). Enzyme $\alpha$-reductase converts testosterone to the more potent form dihydrotestosterone which promotes growth of prostate cells by stimulating the androgen receptor (Liu et al. 2007). Ganoderma lucidum is having a neuroprotective effect caused by the compounds of methyl Ganoderic Acid A, methyl Ganoderic Acid B, Ganoderic Acid -S1 and Ganoderic Acid-TQ, including promoted neuronal survival and reduced fatigue (Zhang et al. 2011, Zhao et al. 2011, Zhao et al. 2012). The potential use of this fungus for the treatment of neurological diseases has also been studied and found that long term consumption of G. lucidum can decrease the progression of Alzheimer's disease (Lai et al. 2008, Zhou et al. 2012). This neuroprotective effect is caused by promotion of neuritogenesis and reduction of senescence of the neurons (Seow et al. 2013). Liu et al (2015b) discovered Ganoderic acid C1 (GAC1) significantly reduced TNF- $\alpha$ production by murine macrophages (RAW 264.7 cells) and peripheral blood mononuclear cells (PBMCs) in asthma patients. Inhibition was associated with down-regulation of NF- $\kappa \mathrm{B}$ expression, and partial suppression of MAPK and AP-1 signaling pathways. Chemical structures of methyl Ganoderic acid A, methyl Ganoderic acid B. Ganoderic acid S1 and Ganoderic acid TQ (Zhang et al. 2011). Ganoderma lucidum is part of several cosmetic products in the Chinese beauty products, many of which are used in the skin lighting function. In an enzyme based assay, G. lucidum extract was found to be potent tyrosinase inhibitor. Tyrosinase enzyme is a key enzyme in the melanin formation. Importantly the IC50 levels were much lower than other Basidiomycetes mushroom, thus justifying its use as a skin lightening active in cosmeceutical products (Chien et al. 2008). Ganoderma lucidum triterpenoids have been improved learning and memory dysfunction of Alzheimer's disease by increasing acetylcholine content in the brain in a rat model (Zhang et al. 2011). Water extracts of G. lucidum inhibit acetylcholine esterase activity in brain tissues and prevent reduction of acetylcholine levels ensuring a protection of brain tissues from cerebral ischemia, vascular dementia and Alzheimer's dementia (Zhang et al. 2014). Memory impairment caused by the lack of acetylcholine due to malfunction of cholinergic nervous system (Choi et al. 2015). Dementia patients with neuronal damage generate only a small amount of acetylcholine even under active acetylcholine esterase enzyme. This results in abnormal neurotransmission and pathological phenomena, such as learning disorders, memory deficits, and cognitive impairment (Talesa 2001). Lee et al. (2011) reported that lanostane triterpenes separated from fruit bodies of $G$. lucidum were exceptional inhibitors of acetylcholine esterase. When activity in brain tissues AChE was examined to determine the efficacy of fermented $G$. lucidum water extracts in improving memory despite scopolamine-induced memory and cognitive impairment, the scopolamine group showed significantly increased AChE activity (Choi et al. 2015).

Pillai \& Devi (2013) revealed the radio protective effect in vivo by $\beta$ - glucan from Ganoderma lucidum in a rat model. GLPS (G. lucidum polysaccharides) had a protective effect against acute hepatotoxicity induced by $\mathrm{CCl}_{4}$ and this protection occurred by scavenging reactive free radicals, inhibiting lipid peroxidation, boosting antioxidant system, suppressing the immune inflammatory response, and restraining extrinsic-induced apoptosis (Liu et al. 2015a). Laboratory tests revealed that the protective efficacy of GLP against EtOH-induced chronic liver injury in SD rats by modulating ethanol metabolizing enzymes activity, attenuating oxidative stress and inhibiting mitochondrial damage-mediated apoptosis (Jang et al. 2015). GLPL (G. lucidum polysaccharide liposome) had significantly enhanced proliferation of the splenic lymphocyte of mice both in single stimulation and synergistical stimulation with PHA (phytohemagglutinin) or LPS (lipopolysaccharide) showing its immunological activity of GLP (Liu et al. 2015a). Ganoderic acid $F$ was found to have the most potent inhibitory effect on the formation of capillary like structures of human umbilical vein endothelial cells showing anti-angiogenesis activity (Nguyen et al. 2015). Ganoderma lucidum water extracts were fermented using lactic acid bacteria and it significantly reduced the inflammation in LPS-stimulated RAW 264.7 cells compared with $G$. 
lucidum water extract alone. Hence, FGWBL (G. lucidum secondary fermented extracts) consumption alone or as a constituent of foods is a viable therapeutic strategy for reduction of inflammation. Shen et al. (2015) demonstrated in vitro permeation studies through rat skin and indicated that the amount of GTs (Ganoderma Triterpenoids) permeated through skin of GT-NLCs (nanostructured lipid carrier) after $24 \mathrm{~h}$ was higher than that of GT emulsion. GT-NLC-gel was found to have superior therapeutic effect for frostbite, compared with the GT emulgel. Zhang et al. (2011) revealed that Ganoderma triterpenes exhibit neurotropic activity. Methyl ganoderate B

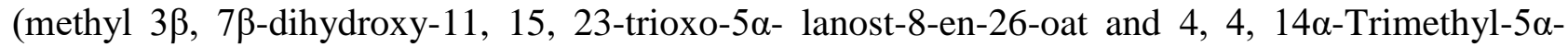
chol-7, 9 (11)-dien-3-oxo-24-oic acid have nerve growth factor-like neuronal survival-promoting effects. Two latter compounds and Methyl ganoderate A (methyl 7 $\beta, 15 \alpha$-dihydroxy-3, 11, 23-

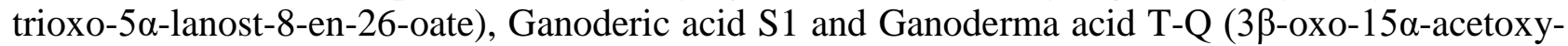
lanosta-7, 9(11), 24-trien- 26-oic acid) showed brain-derived neurotrophic factor-like neuronal survival-promoting activities (Zhang et al. 2011). Compounds $n$-Butyl ganoderate $\mathrm{H}$ ( $n$-butyl 12 $\beta$ acetoxy-3 $\beta$-hydroxy-7,11,15, 23-tetraoxo-5 $\alpha$-lanost-8-en-26-oate) and Methyl ganoderate A acetonide (methyl 7 $\beta, 15 \alpha$-isopropylidenedioxy-3,11,23-trioxo-5 $\alpha$-lanost-8-en-26-oate), exhibiting specific anti-acetylcholinesterase activity, were examined by Lee et al. (2011) as possible drug candidates for the treatment of Alzheimer's and related neurodegenerative diseases. Compounds Lucidadiol (5 $\alpha$-lanosta-8, 24-dien-3 $\beta$, 26-dihydroxy-7-one), Ganodermanondiol, and some other Ganoderma triterpenes exhibited moderate acetylcholinesterase-inhibitory activity, with IC50 values ranging from 9.40 to $31.03 \mu \mathrm{M}$. Hence, lanostane triterpenes are preferential inhibitors of acetylcholinesterase and may be suitable as drug candidates (Lee et al. 2011). Ganoderic acid B $(3 \beta, \quad 7 \beta$-dihydroxy-11, $15, \quad 23$-trioxo-5 $\alpha$-lanost-8-en-26-oic acid showed significant hepatoprotective activity. However, increased doses of compound $3 \beta$, 7 $\beta$-dihydroxy-11, 15, 23 trioxo-5 $\alpha$-lanost-8-en-26-oic acid (up to 10 times) did not further reduce GOT/GPT levels in the serum of the mice ( $\mathrm{Su}$ et al. 1993) Compound Ganosporeric acid A (3, 7, 11, 12, 15, 23-hexaoxo$5 \alpha$-lanosta-8-en-26-oic acid) has an activity of lowering the levels GPT in mice with liver injury by $\mathrm{CCl}_{4}$ and GaNI and exhibits hepatoprotective effects (Chen \& Yu 1993). Lee et al. (2010) revealed, the compound $t$-Butyl lucidenate B ( $t$-butyl 7 $\beta, 12 \beta$-dihydroxy-4, 4, 14 $\alpha$-trimethyl-3, 11, 15-trioxo$5 \alpha$-chol-8-en-24-oate) reduced the triglyceride accumulation significantly and it effectively suppressed the glycerol-3-phosphate dehydrogenase activity in the cells. It suppressed gene expression of PPAR $\gamma, \mathrm{C} / \mathrm{EBP} \alpha$, and SREBP-1c in a dose-dependent manner during differentiation and hence this compound contributes to the inhibitory effect on adipocyte differentiation in 3T3-L1 cells. The inhibitory effect on aldose reductase was examined for Ganoderic acid Df and its methyl ester. Carboxyl group of side chain of compound of Ganoderic acid DF $(7 \beta, 11 \beta$-dihydroxy-3, 15, 23-trioxo-5 $\alpha$-lanosta-8-en-26-oic acid) was found to be essential for potent inhibitory activity because of much lower level of inhibitory activity of its methyl ester (Kinge \& Mih 2011).

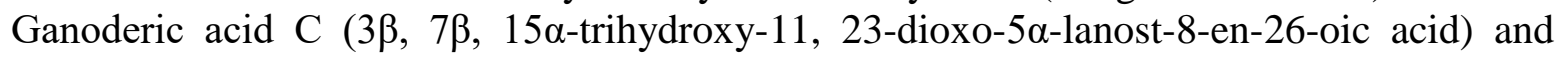
Ganoderic acid D (7 $\beta$-hydroxy-3, 11, 15, 23-tetraoxo-5 $\alpha$-lanost-8-en-26-oic acid) were shown to inhibit histamine release from rat mast cells (Kohda et al. 1985). Butyl ganoderate B and 15Hydroxy-ganoderic acid S (15 $\alpha$-hydroxy-3-oxo-5 $\alpha$-lanosta-7, 9(11), 24(E)-trien-26-oic acid exhibited inhibitory activities against the HMG-CoA reductase and acyl CoA acyl transferase (Li et al. 2006). Ganoderic acid LM2 (23S) 7 $\beta$,-dihydroxy-3,11,15-trioxo-5 $\alpha$-lanosta-8,24-dien-26-oic acid and Ganoderic acid $\varepsilon$ (23S)-3 $\beta, 7 \beta, 23$-trihydroxy-11,15-dioxolanosta-8,24(E)-diene-26-oic acid exhibited potent enhancement of ConA-induced mice splenocytes proliferation in vitro (Luo et al. 2002). It was found that compounds $5 \alpha$-Lanosta-7, 9(11), 24-triene-15 $\alpha$-26-dihydroxy-3-one,

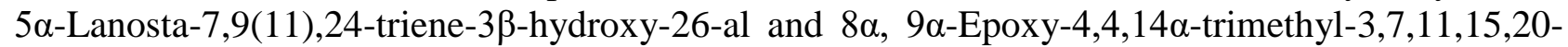
pentaoxo-5 $\alpha$-pregnane possess the bioactivity to induce apoptosis in human promyelocytic leukemia HL-60 cells (Gonsalez et al. 2002). Some Ganoderma triterpenes Ganoderic acid (DM 3, 7-dioxo-8, 24(E)-dien-lanosta-26-oic acid, 5 $\alpha$-Lanosta-7, 9 11), 24-triene-15 $\alpha$-26-dihydroxy-3-one, and Ganoderol A showed inhibitory activity for $5 \alpha$-reductase in rat liver microsomes (Liu et al. 2006). The in vitro tests showed that compounds Fornicatin B (7 $\beta$-hydroxy-11-oxo-3,4-seco25,26,27-trinorlanosta- (28),8-dien-3,24-dioic acid) and Fornicatin A (4, 7 $\beta$-epoxy-28-hydroxy-11- 
oxo-3,4-seco-25,26,27- rinorlanosta-8-en-3,24-dioic acid) showed inhibitory activity against rabbit platelet aggregation induced by platelet activating factor (PAF), and the latter compound exhibited inhibition against platelet aggregation induced by adenosine diphosphate (ADP) (Niu et al. 2004). Chen et al. (2012) found that striatal NGF (nerve growth factor), PGC-1 $\alpha$ (peroxisome proliferator activated receptor- $\gamma$ coactivator $1 \alpha$ ) and succinate dehydrogenase activity were recovered in GaLufed mice (G. lucidum extract) in turn proved that the NGF-signaling pathway connected to the mitochondrial regulator, PGC-1 $\alpha$, expression. This signaling triggered by astrocytic NGF with small molecule inducers may offer a therapeutic strategy for Huntington's disease. Zhang et al. (2013) suggested that GIPS could be used in protecting against alloxan-induced pancreatic islets damage in vitro and in vivo through its scavenging ability to protect the pancreatic islets from free radicals-damage induced by alloxan. Mizushina et al. (1999) revealed Cerevisterol compound could inhibit mammal $\alpha$-DNA polymerase invitro. Ganoderic acids T-Q and lucideinic acids A, D2, E2, and $\mathrm{P}$ showed anti-inflammatory activity in mice (Sliva et al. 2003). Ganoderic acids C and D showed antihistamine releasing activity in rat mast cells (Kohda et al.1985) and Ganoderic acids S1 and C1 showed Glucosyltransferase inhibitory activity (Hada et al. 1989). Ganoderols A and B, Ganoderal A and Ganoderic acid Y had been found to inhibit cholesterol synthesis pathway (Hajjaj et al. 2005). Seo et al. (2009) confirmed anti-complimentary activity against the classical pathway of the complement system. Ganodermic acid S induces platelet aggregation at high dosages and inhibit agonist- induced platelet aggregation at low dosages (Su et al.1999, Shiao 2003). Liang et al. (2014) found that Ganoderma lucidum polysaccharides have anti-inflammatory property that could be useful in the prevention of vascular diseases and inflammatory responses by decreasing IL-1 $\beta$ expression. Hsu et al. (2012) found extract of G. lucidum can modulate human immunity by activating human PMNs via the p38 MAPK pathway. Weng et al. (2010) reported Ganodermasides $\mathrm{A}$ and $\mathrm{B}$ as anti-aging compounds.

Yang et al. (2013) confirmed osteogenic potential of Ganoderma lucidum by studying osteogenetic capability of Ling Zhi-8 compared with recombinant human bone morphogenic protein-2 (rhBMP-2) in a standardized bony defect using a rabbit sinus model. The biomaterial implants using rhBMP-2 and LZ-8 had good biocompatibility and osteogenetic capabilities in the rabbit sinus model. Bone healing in rhBMP-2-treated defects was excellent and showed a significant difference compared with LZ-8. However, LZ-8-treated defects also exhibited bone regeneration, and this traditional Chinese medicine may possess osteogenic potential. Liu et al (2015a) reported GAC1 (Triterpene Ganoderic acid C1) inhibited production of TNF- $\alpha$ (Tumor necrosis factor- $\alpha$ ) and other pro inflammatory cytokines by PBMCs (Peripheral blood mononuclear cells) and inflamed CD (Crohn's disease) colonic mucosa due to blockage of NF- $\kappa \mathrm{B}$ activation (Nuclear factor-кB). The water extract of G. lucidum mycelium (WEGL) reduces body weight, inflammation and insulin resistance in mice fed a high-fat diet (HFD) by reversing HFD-induced gut dysbiosis (Chang et al. 2015). Further, it maintains intestinal barrier integrity, reduces metabolic endotoxemia and shows that high molecular weight polysaccharides $(>300 \mathrm{kDa})$ isolated from the WEGL extract produce similar anti-obesity and microbiota-modulating effects. Thyagarajan-Sahu et al. (2011) demonstrated ReishiMax (RM), a nutritional supplement made by G. lucidum can control adipocyte differentiation by inhibiting suppression of expression of adipogenic transcription factors peroxisome proliferator-activated receptor- $\gamma$ (PPAR- $\gamma$ ), sterol regulatory element binding element protein-1c (SREBP-1c) and CCAAT/enhancer binding protein$\alpha(\mathrm{C} / \mathrm{EBP}-\alpha)$. ReishiMax suppressed expression of enzymes and proteins responsible for lipid synthesis, transport and storage: fatty acid synthase (FAS), acyl-CoA synthetase-1 (ACS1), fatty acid binding protein-4 (FABP4), fatty acid transport protein-1 (FATP1) and perilipin, Further RM induced, AMP-activated protein kinase (AMPK) and increased glucose uptake in 3T3-L1 cells by adipocytes. Ganoderma lucidum extracts enhanced the ability to mount humoral responses against viral infection in broiler chickens (Ojiezeh \& Eghafona 2015). Chu et al. (2007) reported $G$. lucidum aqueous extract (GLE) on sleep and its sedative activity in a rat model. GLE significantly decreased sleep latency, increased sleeping time, non-REM sleep time and light sleep time in pentobarbital-treated rats. Hence GLE may be having benzodiazepine like hypnotic activity. 


\section{Toxicity}

Most papers on Ganoderma lucidum focused on its miraculous healing quantities but few have shown that it can have toxic effects on humans. Studies on the toxicity and adverse effects of G. lucidum are much less common, however, in vitro study revealed that G. lucidum extracts can have the potential to cause toxicity. When G. lucidum extracts exposed to cells at higher levels of concentrations than which required for stimulatory effects, it causes significant reduction in cell viability observed in some cell lines (Gill \& Rieder 2008). Human sensitization to G. lucidum antigen was first reported in 1979 in Ontario, CA, USA with patients who attended chest and allergy clinics and found positive to the Ganoderma antigen (Tarlo et al. 1979) and similar study was done in 1985 in Auckland, New Zealand with more positive data for G. lucidum allergy (Cutten et al. 1988). In 1995 sensitization was reported in India with patients which showed marked skin reactivity to spore and whole body extracts of G. lucidum (Singh et al. 1995). Wanmuang et al. (2007) reported hepatotoxic effects from a patient in Hong Kong who was under the treatments of G. lucidum spore powder. Patients with hypoglycemia should be treated very carefully with $G$. lucidum since it lowers the blood sugar level (Hikino et al. 1989). Tao et al. (1990) with blood disorders like Thrombocytopenia and patients who were taking anticoagulants or antiplatelets should be cautious, since G. lucidum has anticoagulant effects. Further, patients with gastric ulcers and active gastrointestinal bleeding should be vigilant because of apparent anticoagulant effect of G. lucidum. Patients with tendency for bleeding should be cautious since G. lucidum has an additive effect on clotting factors and prolongation of Prothrombin time (Ulbricht et al. 2010). Patients who are under treatments for Hypertension should be very careful as G. lucidum has hypotensive properties (Lee et al. 2001). Ganoderma lucidum is not recommended for lactating women and pregnant women since no scientific data was found on effects of lactation (Ulbricht et al. 2010). Ganoderma lucidum extract increased total sleep time and non-rapid eye movement significantly in rats, with a possible mechanism related to TNF- $\alpha$ (Cui et al. 2012). Gao et al. (2002 a) reported that GLPS produced a mucosal healing effect in the rat model, partially due to the suppression of TNF- $\alpha$ and induction of c-myc and ODC gene. Ganoderma lucidum pharmacopuncture (GLP) on chronic gastric ulcers in rats was studied by Park et al. (2014) and found two local acupoints CV12 and ST36 can provide significant protection to the gastric mucosa. Aqueous extracts from G. lucidum showed absence of embryotoxic or neurotoxic effects when incubated with mouse embryonic fibroblast (BALB/3T3) and mouse neuroblastoma (N2a) cells (Smiderle et al. 2015).

\section{Discussion}

\section{Are the beneficial medical properties truly substantiated?}

Ganoderma lucidum has a very ancient history as a medicinal mushroom hence it has gained an almost divine status in its usage to promote health. This fungus is now becoming accepted as a natural adjuvant supplement in combination with other therapies to enhance the healing effects by supporting the immune system. Recent in vitro and in vivo studies demonstrate the beneficial effects of G. lucidum on various diseases and the Western medical researchers are increasingly involved to study this topic nowadays, since this mushroom was introduced to the Western world only within the past 30 years. However, to confirm if G. lucidum has healing power or not, there is a need for a deeper scientific understanding of medical properties, mechanisms of actions, and their interrelationships with other molecules. Published medical investigations performed on G. lucidum except anticancer, are compiled in Table 1. Very few studies have been conducted with $G$. lucidum in human patients. Most of the studies were performed with small sample size without a placebo control group (Fu \& Wang 1982, Kanamatsuse et al. 1985, Jun \& Ke-yan 1990, Soo 1994, Wanachiwanawin et al. 2006, Wanmuang et al. 2007, Nayak et al. 2015). Further, there is a lack of information regarding long term treatment of the drug, age, patient's gender (Kanamatsuse et al. 1985, Jin et al. 1996, Hijikata \& Yamada 1998, Futrakul et al. 2002), side effects, standard method of extraction of G. lucidum, its standard dosage and number of 
Table 1 Clinical trials performed with Ganoderma lucidum preparations.

\begin{tabular}{|c|c|c|c|c|}
\hline Clinical trial & Disease Type & Dose & Effect & References \\
\hline $\begin{array}{l}\text { Preliminary, open label study (no } \\
\text { randomization, blinding } \\
\text { or placebo control), } \\
10 \text { patients ( } 8 \text { males and } 2 \text { females) } \\
\text { were treated under water soluble } G \text {. } \\
\text { lucidum spores (Institute of Materia } \\
\text { Medica). }\end{array}$ & $\begin{array}{l}\text { Atrophic Myotonia } \\
\text { (Myotonia } \\
\text { dystrophica). }\end{array}$ & $\begin{array}{l}400 \mathrm{mg} \text { per day for } 2 \text { weeks, } \\
\text { then the treatment was } \\
\text { continued up to } 8 \text { months to } \\
6.8 \text { years. }\end{array}$ & $\begin{array}{l}\text { After } 2 \text { weeks of treatment, sleep, weight gain, } \\
\text { physical strength and muscular strength and relief of } \\
\text { Myotonia improved in all patients. Two reported } \\
\text { improvement, and } 3 \text { reported slight improvement in } \\
\text { muscle strength with mytonic symptoms relieved. } \\
\text { Six patients displayed at least some long-term results. }\end{array}$ & $\begin{array}{l}\text { Fu \& Wang } \\
1982, \quad \text { Frost } \\
2016\end{array}$ \\
\hline $\begin{array}{l}\text { Clinical trial (no } \\
\text { randomization, } \\
\text { blinding, or } \\
\text { placebo control) } 53 \text { patients were } \\
\text { treated with lyophilized G. lucidum } \\
\text { extract } \\
\text { tablets }(240 \mathrm{mg}) .\end{array}$ & $\begin{array}{l}\text { Essential } \\
\text { hypertension } \\
\text { Mild hypertension. }\end{array}$ & $\begin{array}{l}6 \text { tablets/day } \\
(1440 \\
\text { mg/day })\end{array}$ & $\begin{array}{l}\text { Blood pressure decreased significantly in essential } \\
\text { hypertension patients and slightly decrease in patients } \\
\text { with mild hypertension, total cholesterol decreased } \\
\text { and fibrinogen increased slightly. }\end{array}$ & $\begin{array}{l}\text { Kanmatsuse et } \\
\text { al. } 1985, \\
\text { Frost } 2016\end{array}$ \\
\hline $\begin{array}{l}15 \text { volunteers and } 33 \text { atherosclerotic } \\
\text { patients were orally treated with } G \text {. } \\
\text { lucidum extract. }\end{array}$ & Atherosclerosis. & $\begin{array}{l}1 \mathrm{~g} \text { of } G . \text { lucidum } 3 \text { times per } \\
1 \text { day for } 2 \text { weeks. }\end{array}$ & $\begin{array}{l}\text { Length and weights (wet and dry) of the } \\
\text { extracorporeal thrombi were reduced, maximum } \\
\text { platelet aggregation inhibition rates were then } 31.49 \\
\% \text { and } 17.7 \% \text {. Effective inhibitory agent of platelet } \\
\text { aggregation. }\end{array}$ & $\begin{array}{l}\text { Jun \& Ke-yan } \\
1990\end{array}$ \\
\hline $\begin{array}{l}4 \text { patients were treated with } G . \\
\text { lucidum extract. }\end{array}$ & $\begin{array}{l}\text { Hepatitis B and } \\
\text { elevated bilirubin and } \\
\text { SGPT/SGOT levels } \\
\text { (alanine } \\
\text { aminotransferase and } \\
\text { aspartate } \\
\text { aminotransferase. }\end{array}$ & $\begin{array}{l}6 \mathrm{~g} \text { of } G . \text { lucidum extract } \\
\text { daily } \\
\text { undefined) for } 3 \text { months. }\end{array}$ & $\begin{array}{l}\text { After } 1 \text { month, bilirubin, SGPT, and SGOT levels } \\
\text { were significantly reduced, after } 90 \text { days all values } \\
\text { returned to within normal ranges. }\end{array}$ & Soo 1994 \\
\hline $\begin{array}{l}\text { Placebo controlled double blind trial, } \\
54 \text { patients were treated with tablets } \\
\text { containing G. lucidum extract } \\
\text {, each } 55 \mathrm{mg}= \\
\text { 1.375g of sporophores } \\
\text { (Wakan Shoyaku } \\
\text { Botany Institute). }\end{array}$ & Stage II hypertension. & $\begin{array}{l}2 \text { tablets } \\
\text { orally, } \\
3 \text { times/day } \\
(330 \mathrm{mg} / \text { day }\end{array}$ & $\begin{array}{l}\text { After } 1 \text { week systolic and diastolic blood pressure } \\
\text { significantly drop, after } 2 \text { weeks significant change in } \\
\text { nail fold micro circulation, improvements in capillary } \\
\text { loop density, diameter and red blood cell velocity }\end{array}$ & Jin et al. 1996 \\
\hline $\begin{array}{l}\text { Administration of hot water soluble } \\
\text { extracts of Ganoderma lucidum for } \\
\text { two patients with post herpetic } \\
\text { neuralgia, } 2 \text { other patients with severe } \\
\text { pain due to herpes zoster infection. }\end{array}$ & $\begin{array}{lr}\text { Post } & \text { herpetic } \\
\text { neuralgia and } & \\
\text { Herpes } & \text { zoster } \\
\text { infection. } & \end{array}$ & 36 to $72 \mathrm{~g}$ dry weight/day. & Decreased pain drastically. & $\begin{array}{l}\text { Hijikata \& } \\
\text { Yamada } 1998\end{array}$ \\
\hline
\end{tabular}




\begin{tabular}{|c|c|c|c|c|}
\hline Clinical trial & Disease Type & Dose & Effect & References \\
\hline $\begin{array}{l}10 \text { necrotic patients treated with crude } \\
\text { extract of } G \text {. lucidum, } 5 \text { of them } \\
\text { received } G \text {. lucidum and vasodilators } \\
\text { both. } \\
\text { Other } 5 \text { received vasodilators only. }\end{array}$ & Proteinuria. & $\begin{array}{l}750 \text { to } 1100 \mathrm{mg} \text { of } G . \\
\text { lucidum daily for } 1 \text { year. }\end{array}$ & $\begin{array}{l}\text { Urinary protein level drops by } 85 \% \text { in G. lucidum } \\
\text { treated patients and others by } 11 \% \\
\text { only. }\end{array}$ & $\begin{array}{l}\text { Futrakul et al. } \\
2002\end{array}$ \\
\hline $\begin{array}{l}\text { Phase I/II randomized, } \\
\text { placebo controlled } \\
\text { clinical trial, } 78 \text { patients with } \\
\text { chronic hepatitis B; } \\
\text { treated with Ganopoly, } 1 \text { capsule = } \\
600 \text { mg extract } \\
\text { equivalent to } 9 \text { g of } \\
\text { fruiting body (provided } \\
\text { by Encore International } \\
\text { Co. Auckland, NZ). }\end{array}$ & $\begin{array}{l}\text { Chronic } \\
\text { hepatitis B. }\end{array}$ & $\begin{array}{l}3 \text { capsules, } \\
3 \text { times/day } \\
\text { before meals } \\
\text { ( } 5400 \\
\text { mg/day), } \\
12 \text { weeks } \\
\text { treatment } \\
\text { and } 12 \\
\text { weeks } \\
\text { follow-up. }\end{array}$ & $\begin{array}{l}\text { Decreased level of hepatitis B virus DNA and } \\
\text { hepatitis B e-antigens occurred in } 25 \% \text { of the } \\
\text { treatment group vs. } 4 \% \text { of the control group. The } \\
\text { number of treated patients with normal } \\
\text { aminotransferase values was } 33 \% \text { and } 13 \% \text { had } \\
\text { cleared hepatitis B surface antigens vs. } 0 \% \text { of control } \\
\text { patients. Results indicate that Ganopoly is well } \\
\text { tolerated and } \\
\text { appears to be active against HBV in patients with } \\
\text { chronic hepatitis B. }\end{array}$ & $\begin{array}{l}\text { Gao et al. } \\
2002 \mathrm{a}\end{array}$ \\
\hline $\begin{array}{l}\text { Double blinded placebo controlled } \\
\text { cross-over intervention study. Fasting } \\
\text { blood and urine from healthy, } \\
\text { consenting } 18 \text { adults (aged 22-52 } \\
\text { years) was collected before and after } 4 \\
\text { weeks supplementation with } G \text {. } \\
\text { lucidum and or placebo. }\end{array}$ & $\begin{array}{l}\text { Ganoderma lucidum } \\
\text { supplementation on a } \\
\text { range of biomarkers } \\
\text { for antioxidant status, } \\
\text { CHD. (Coronary } \\
\text { Heart disease) risk, } \\
\text { DNA damage, } \\
\text { immune status, and } \\
\text { inflammation. }\end{array}$ & $\begin{array}{l}\text { Commercially } \begin{array}{r}\text { available } \\
\text { encapsulated } G . \quad \text { lucidum }\end{array} \\
\text { (Lingzhi) preparation }(1 \cdot 44 \\
\text { g Lingzhi/d; equivalent to } \\
13 \cdot 2 \text { g fresh mushroom/d) or } \\
\text { placebo. }\end{array}$ & $\begin{array}{l}\text { No significant change in any of the variables, but a } \\
\text { slight trend toward lowering lipids, increased } \\
\text { antioxidant capacity in urine. No evidence of liver, } \\
\text { renal or DNA toxicity with G. lucidum intake. }\end{array}$ & $\begin{array}{l}\text { Wachtel-Galor } \\
\text { et al. } 2004\end{array}$ \\
\hline $\begin{array}{l}14 \text { RSP patients were treated with } G \text {. } \\
\text { lucidum decoction }(1 \text { dose is } 100 \mathrm{~g} \text { of } G \text {. } \\
\text { lucidum and water } 600 \mathrm{ml}) \text { together } \\
\text { with conventional treatment. }\end{array}$ & $\begin{array}{l}\text { RSP patients } \\
\text { (Russula } \\
\text { subnigricans } \\
\text { poisoning). }\end{array}$ & Not mentioned. & $\begin{array}{l}\text { Significantly decreased urinary protein and blood cell } \\
\text { count. }\end{array}$ & Xiao et al. 2003 \\
\hline $\begin{array}{l}\text { A double-blind, randomized, placebo- } \\
\text { controlled trial, } 170 \text { patients treated } \\
\text { with Ganopoly, } 1 \text { capsule }=600 \mathrm{mg} \\
\text { extract equivalent to } 9 \mathrm{~g} \text { of fruiting } \\
\text { body (provided by Encore }\end{array}$ & $\begin{array}{l}\text { Coronary Heart } \\
\text { Disease. }\end{array}$ & $\begin{array}{l}3 \text { capsules, } \\
3 \text { times per day } \\
\text { before meals } \\
\text { ( } 5400 \mathrm{mg} \text { per day). }\end{array}$ & $\begin{array}{l}\text { Treatment improved primary symptoms, decreased } \\
\text { abnormal electrocardiogram appearance, and } \\
\text { decreased blood pressure and cholesterol in } \\
\text { comparison to the control group. }\end{array}$ & Gao et al. 2004b \\
\hline $\begin{array}{l}\text { International Co. Auckland, NZ), } \\
\text { Phase I/IIA randomized non blinded } \\
\text { placebo controlled multicenter clinical } \\
\text { trial, } 71 \text { patients treated with } \\
\text { Ganopoly } 1 \text { capsule }=600 \mathrm{mg} \text { extract } \\
=9 \mathrm{~g} \text { of fruiting body (provided } \\
\text { by Encore International Co. }\end{array}$ & $\begin{array}{l}\text { Type II Diabetes } \\
\text { mellitus. }\end{array}$ & $\begin{array}{l}1800 \mathrm{mg} \text { Ganopoly was used } \\
3 \text { times daily for } 12 \text { weeks. }\end{array}$ & $\begin{array}{l}\text { Statistically significant decrease in glycosylated } \\
\text { hemoglobin was observed in the treated group in } \\
\text { comparison with the control group. The results } \\
\text { suggest that Ganopoly is efficacious and safe in } \\
\text { lowering blood glucose concentrations. }\end{array}$ & Gao et al. 2004a \\
\hline
\end{tabular}







In 123 patients, lower scores after 8 weeks in the CGI

controlled study, 132 patients with

neurasthenia treated with Ganopoly.
Pseudoparasitosis caused due to $G$. Pseudoparasitosis

lucidum, first reported case in

Thailand. A 49 years old male patient

with non-Hodgkin's lymphoma

showed chronic watery diarrhea. He

had a history of consumption of

powdered G. lucidum extract as a

dietary supplement and herbal

medicine. Stool examination

confirmed many spores of G. lucidum.

Hepatotoxic effect related to $G$. Fatal

lucidum mushroom, $G$. lucidum hepatitis

powder was treated for two patients.

A double-blind, randomized, placebo- Rheumatoid arthritis. controlled pilot trial on

safety and efficacy of $G$. lucidum and

San miao San supplementation in patients

with rheumatoid arthritis. 32 patients with active

rheumatoid arthritis despite diseasemodifying antirheumatic drugs received

G. lucidum and San Miao San and 33 patients a placebo

in addition to their current medications.

A double-blind, randomized, placebocontrolled trial, Oral administration of $G$. lucidum in 16 human volunteers. During the study, information from
No specific disease, only volunteers.

Not mentioned.

of fatigue, with a respective reduction of $15.5 \%$ and $28.3 \%$ from baseline, whereas the reductions in the placebo group were $4.9 \%$ and $20.1 \%$, well tolerated in the study patients, Ganopoly was significantly superior to placebo with respect to the clinical improvement of symptoms in neurasthenia.

After discontinuation of mushroom spores ingestion, Wanachiwanawi the diarrheal symptoms improved but fecal n et al. 2006 examination subsequently showed no Ganoderma spores. Many artifacts in the stool may be confused with parasites.

Showed hepatotoxic effect after 1 or 2 months in both patients.

owder for 1-2 months, no

specific dosage was

Ganoderma and San Miao San $(2.4 \mathrm{~g})$,

for 24 weeks.

Ganoderma lucidum and San Miao San preparation may have analgesic effects for patients with active rheumatoid arthritis, and were generally safe and well tolerated. no significant antioxidant, antiinflammatory, or immunomodulating effects could be demonstrated.

$2 \mathrm{~g}$ of the G. lucidum extract or placebo twice daily for 10 days.
Compared to placebo group, no adverse effects were observed, no obvious changes in $\mathrm{CD} 4, \mathrm{CD} 8$, and CD19 levels after the extract, CD56 cell count increased during the study and returned to baseline 


\begin{tabular}{|c|c|c|c|c|}
\hline Clinical trial & Disease Type & Dose & Effect & References \\
\hline  & & & 10 days after the treatment. & \\
\hline $\begin{array}{l}\text { Randomized, double-blind, } \\
\text { placebo controlled, dose-ranging } \\
\text { clinical trial } 50 \text { men with lower } \\
\text { urinary tract } \\
\text { symptoms; group 1: }(\mathrm{n}=12) \text {; } \\
\text { group 2: }(\mathrm{n}=12) \text {; group 3: }(\mathrm{n}=14) \text {, } \\
\text { control: }(\mathrm{n}=12) \text { G. lucidum tablets } \\
\text { (Chlorella Industry } \\
\text { Tokyo, Japan). }\end{array}$ & $\begin{array}{l}\text { Lower urinary } \\
\text { tract symptoms. }\end{array}$ & $\begin{array}{l}\text { group } 1: \\
0.6 \mathrm{mg} / \text { day; } \\
\text { group 2: } \\
6 \mathrm{mg} / \text { day; } \\
\text { group 3: } \\
60 \mathrm{mg} / \text { day } \\
8 \text { weeks. }\end{array}$ & $\begin{array}{l}\text { There were no statistically significant differences in } \\
\text { baseline characteristics for age, PSA level, prostate } \\
\text { volume, peak urinary flow rate, or symptom score } \\
\text { among the treatment groups vs control; however, the } \\
\text { treatment groups receiving } 6 \mathrm{mg} \text { and } 60 \mathrm{mg} \text { had } \\
\text { significantly improved International Prostate } \\
\text { Symptom Scores. No major adverse effects were } \\
\text { observed. }\end{array}$ & $\begin{array}{l}\text { Noguchi et al. } \\
2008 \mathrm{a}\end{array}$ \\
\hline $\begin{array}{l}\text { Double-blind, placebo-controlled, } \\
\text { randomized and dose-ranging study } \\
\text { with } 88 \text { men over the age of } 49 \text { years } \\
\text { who had slight-to-moderate LUTS } \\
\text { were treated with G. lucidum tablets } \\
\text { (Chlorella Industry } \\
\text { Tokyo, Japan). }\end{array}$ & $\begin{array}{l}\text { Lower urinary tract } \\
\text { symptoms (LUTS). }\end{array}$ & $\begin{array}{l}12 \text { weeks of treatment with } \\
\text { G. lucidum extract, } 6 \mathrm{mg} \\
\text { once a day or placebo. }\end{array}$ & $\begin{array}{l}\text { A statistically significant improvement in the } \\
\text { International Prostate Symptom Score in the } \\
\text { treatment group vs. control. Overall treatment was } \\
\text { well tolerated with no severe adverse effects. }\end{array}$ & $\begin{array}{l}\text { Noguchi et al. } \\
2008 b\end{array}$ \\
\hline $\begin{array}{l}\text { Randomized, double-blind, crossover } \\
\text { study with placebo controlled run-in } \\
\text { and cross-over } \\
\text { periods. } 26 \text { patients were treated. }\end{array}$ & $\begin{array}{l}\text { Patients with } \\
\text { borderline elevations } \\
\text { of blood pressure } \\
\text { and/or cholesterol } \\
\text { (Hypertension). }\end{array}$ & $\begin{array}{l}1.44 \text { G. lucidum daily or } \\
\text { matching placebo for } 12 \\
\text { weeks. }\end{array}$ & $\begin{array}{l}\text { Plasma insulin and homeostasis model assessment- } \\
\text { insulin resistance were lower in the treatment group } \\
\text { than in the placebo group. }\end{array}$ & Chu et al. 2012 \\
\hline $\begin{array}{l}\text { A randomized placebo controlled } \\
\text { multi-center study, } 90 \text { chronic } \\
\text { hepatitis B patients were treated with } \\
\text { Ganopoly. }\end{array}$ & chronic hepatitis B. & $\begin{array}{l}\text { Ganopoly dose unknown, } \\
\text { treated } 12 \text { weeks and } \\
\text { followed } 13 \text { weeks. }\end{array}$ & $\begin{array}{l}\text { Reduced the HBV DNA level of } 25 \% \text { of patients with } \\
4 \% \text { compared to placebo, after } 6 \text { months } 33 \% \text { had } \\
\text { normal aminotransferase values, } 13 \% \text { had lost } \\
\text { hepatitis B surface antigen(HBsAg) from serum, } \\
\text { none of the controls showed had normal } \\
\text { aminotransferase values or had lost hepatitis B } \\
\text { surface antigen (HBsAg). }\end{array}$ & Gao et al. 2012 \\
\hline $\begin{array}{l}472 \text { patients who underwent oral } \\
\text { swabs for gingivitis and } 61 \text { patients } \\
\text { were positive for HPV16 (Oral } \\
\text { Human papilloma virus) or HPV18. }\end{array}$ & $\begin{array}{l}\text { Patients with HPV16 } \\
\text { and HPV18. }\end{array}$ & Not mentioned. & $\begin{array}{l}\text { After } 2 \text { months, in group } 1 \text {, the clearance was equal } \\
\text { to } 5 \% \text {. In group } 2 \text {, the clearance was equal to } 88 \% \text {. } \\
\text { The use of TV+GL for the clearance of oral HPV was } \\
\text { effective. }\end{array}$ & Donatini 2014 \\
\hline
\end{tabular}




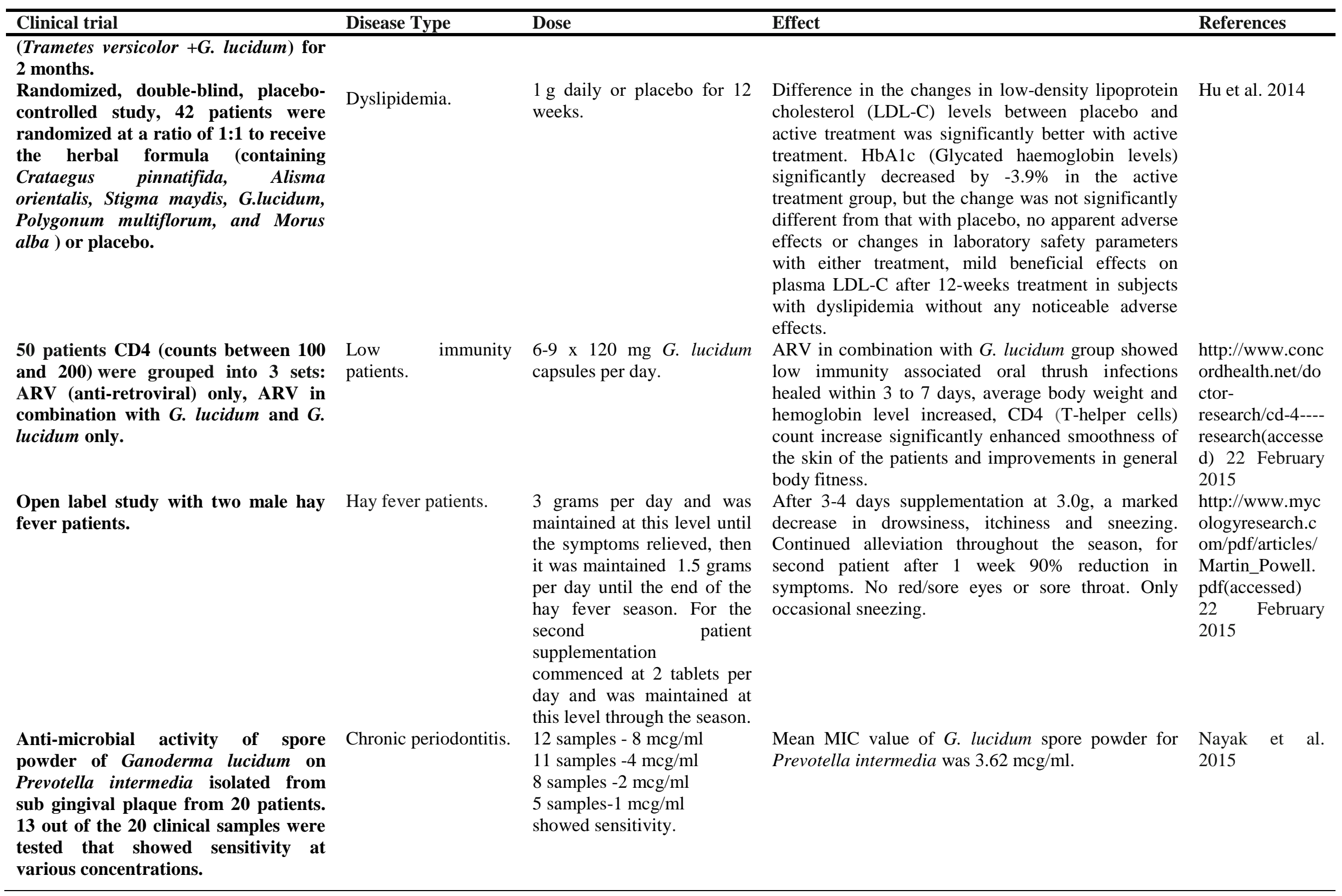


patients treated, further available information on the number of trials and patients enrollment was very limited. However, well designed in vivo tests and randomized controlled clinical studies with G. lucidum can provide statistically significant results to confirm the efficacy and safety of $G$. lucidum preparations. Work on the identification of active ingredients, isolation and purification of individual compounds should be carried out and this will enable the active ingredients within nutriceutical products to be measured and to understand whether the beneficial compounds in $G$. lucidum act synergistically or independently, and to explain potential synergistic effects and establish safe and beneficial dose ranges of active ingredients for each disease type. Further, standardization and quality control of G. lucidum strains, cultivation processes, extracts and commercial formulations, are needed to accept G. lucidum as a natural product for potential use in the prevention and treatment of various diseases. In the nearest future, studies on this medicinal mushroom will be conducted on broad scale with standard scientific methods. These products are recommended for adjutant therapy or alternative mode of medicine but not for direct cure of any diseases. These can improve the comfort of patients' lives or prevent certain diseases or to support drug treatment in chronic diseases to reduce side effects. However, clearly defined protocols and medical standards on exact bioactive compounds and improved culture conditions should be incorporated.

\section{Conclusion}

There has been significant increase in developing natural drugs all over the world and Ganoderma lucidum has been used as a functional food to prevent and treat many immunological diseases over the last few decades. Some in vitro and in vivo studies of medicinal properties of $G$. lucidum appear to be promising, but more in-depth investigation and accurate scientific evidence is still required to confirm the efficacy and safety of the drug in order to incorporate G. lucidum as an integrative therapy.

\section{Acknowledgements}

This work was financed by the Science Research Foundation of Guizhou University (No. 201309), the featured microbial resources and diversity investigation in Southwest Karst area (2014FY120100) and Thailand Research Fund Grant - Taxonomy, Phylogeny and Biochemistry of Thai Basidiomycetes (BRG 5580009). Kalani K. Hapuarachchi is grateful to Asanka R. Bandara, Ishani D. Goonasekara, Ningguo Liu and Yong-Zhong Lu for their valuable suggestions and help.

\section{References}

Adams M, Christen M, Plitzko I, Zimmermann S, Brun R, Kaiser M, Hamburger M. 2010 Antiplasmodial lanostanes from the Ganoderma lucidum mushroom. Journal of Natural Products 73(5), 897-900.

Agius L 2007 - New hepatic targets for glycaemic control in diabetes. Best practice \& Research Clinical Endocrinology \& Metabolism 21(4), 587-605.

Anthony MP, Burrows JN, Duparc S, JMoehrle J, Wells TN. 2012 - The global pipeline of new medicines for the control and elimination of malaria. Malaria Journal 11(1), 316. doi: 10.1186/1475-2875-11-316.

Bhatnagar A, Srivastava SK. 1992 - Aldose reductase: congenial and injurious profiles of an enigmatic enzyme. Biochemical Medicine and Metabolic Biology 48(2), 91-121.

Bisko NA, Mitropolskaya NY. 1999 - Some biologically active substances from medicinal mushroom Ganoderma lucidum. International Journal of Medicinal Mushrooms 5(3), 301.

Boh B. 2013 - Ganoderma lucidum: A Potential for Biotechnological Production of Anti-Cancer and Immunomodulatory Drugs. Recent Patents on Anti-Cancer Drug Discovery 8(3), 255287.

Cao Y, Wu SH, Dai YC. 2012 - Species clarification of the prize medicinal Ganoderma mushroom “Lingzhi'”. Fungal Diversity 56(1), 49-62. 
Chang CJ, Lin CS, Lu CC, Martel J, Ko YF, Ojcius DM, Tseng SF, Wu TR, Chen YY, Young JD, Lai HC. 2015 - Ganoderma lucidum reduces obesity in mice by modulating the composition of the gut microbiota. Nature Communications 6, 7489. doi: 10.1038/ncomms 8489.

Chang ST, Buswell JA. 1996 - Mushroom nutriceuticals. World Journal of Microbiology and Biotechnology 12(5), 473-6.

Chang ST, Buswell JA. 1999 - Ganoderma lucidum (Curt. Fr.) P. Karst. (Aphyllophoromycetideae) - A mushrooming medicinal mushroom. International Journal of Medicinal Mushrooms 1, 139-146.

Chen J, Zhou J, Zhang L, Nakamura Y, Norisuye T. 1998 - Chemical structure of the waterinsoluble polysaccharide isolated from the fruiting body of Ganoderma lucidum. Polymer Journal 30(10), 838-842.

Chen RY, Yu DQ. 1993 - Studies on the triterpenoid constituents of the spores from Ganoderma lucidum Karst. Journal of Chinese Pharmaceutical Sciences 2(2), 91-96.

Chen S, Xu J, Liu C, Zhu Y, Nelson DR, Zhou S, Li C, Wang L, Guo X, Sun Y, Luo H, Li Y, Song J, Henrissat B, Levasseur A, Qian J, Li J, Luo X, Shi L, He L, Xiang L, Xu X, Niu Y, Li Q, Han MV, Yan H, Zhang J, Chen H, Lv A, Wang Z, Liu M, Schwartz DC, Sun C. 2012 Genome sequence of the model medicinal mushroom Ganoderma lucidum. Nature Communications 3, 913. doi: 10.1038/ncomms 1923

Cheng PG, Phan CW, Sabaratnam V, Abdullah N, Abdulla MA, Kuppusamy UR. 2013 Polysaccharides-Rich Extract of Ganoderma lucidum (M.A. Curtis: Fr.) P. Karst Accelerates Wound Healing in Streptozotocin-Induced Diabetic Rats. Evidence-Based Complementary and Alternative Medicine 671252, doi: 10.1155/2013/671252

Chien CC, Tsai ML, Chen CC, Chang SJ, Tseng CH. 2008 - Effects of tyrosinase activity by the extracts of Ganoderma lucidum and related mushrooms. Mycopathologia 166(2), 117-120.

Chiu SW, Wang ZM, Leung TM, Moore D. 2000 - Nutritional value of Ganoderma extract and assessment of its genotoxicity and antigenotoxicity using comet assays of mouse lymphocytes. Food and Chemical Toxicology 38(2), 173-178.

Choi YJ, Yang HS, Jo JH, Lee SC, Park TY, Choi BS, Seo KS, Huh CK. 2015 - Anti-Amnesic Effect of Fermented Ganoderma lucidum Water Extracts by Lactic Acid Bacteria on Scopolamine-Induced Memory Impairment in Rats. Preventive Nutrition and Food Science 20(2), 126-132.

Chu QP, Wang LE, Cui XY, Fu HZ, Lin ZB, Lin SQ, Zhang YH. 2007 - Extract of Ganoderma lucidum potentiates pentobarbital-induced sleep via a GABAergic mechanism. Pharmacology Biochemistry and Behavior 86(4), 693-698.

Chu TT, Benzie IF, Lam CW, Fok BS, Lee KK, Tomlinson B. 2012 - Study of potential cardioprotective effects of Ganoderma lucidum (Lingzhi): Results of a controlled human intervention trial. British Journal of Nutrition 107(7), 1017-27.

Combs AP 2010 - Recent advances in the discovery of competitive protein tyrosine phosphatase 1B inhibitors for the treatment of diabetes, obesity, and cancer. Journal of Medicinal Chemistry 53(6), 2333-2344.

Cui XY, Cui SY, Zhang J, Wang ZJ, Yu B, Sheng ZF, Zhang XQ, Zhang YH. 2012 - Extract of Ganoderma lucidum prolongs sleep time in rats. Journal of Ethno pharmacology 139(3), 796-800.

Cutten AE, Hasnain SM, Segedin BP, Bai TR, McKay EJ. 1988 - The basidiomycete Ganoderma and asthma: collection, quantitation and immunogenicity of the spores. The New Zealand Medical Journal 101, 361-363.

Dai YC, Yang ZL, Cui BK, Yu CJ, Zhou LW. 2009 - Species diversity and utilization of medicinal mushrooms and fungi in China. International Journal of Medicinal Mushrooms 11, 287 302. 
Donatini B 2014 - Control of oral human papillomavirus (HPV) by medicinal mushrooms, Trametes versicolor and Ganoderma lucidum: a preliminary clinical trial. International Journal of Medicinal Mushrooms 16(5), 497-498.

El-Mekkawy S, Meselhy MR, Nakamura N, Tezuka Y, Hattori M, Kakiuchi N, Shimotohno K, Kawahata T, Otake T. 1998 - HIV-1 and anti-HIV-1-protease substances from Ganoderma lucidum. Phytochemistry 49(6), 1651-7.

Eo SK, Kim YS, Lee CK, Han SS. 2000 - Possible mode of antiviral activity of acidic protein bound polysaccharide isolated from Ganoderma lucidum on herpes simplex viruses. Journal of Ethnopharmacology 72(3), 475-481.

Fatmawati S, Kondo R, Shimizu K. 2013 - Structure-activity relationships of lanostane-type triterpenoids from Ganoderma lingzhi as alpha-glucosidase inhibitors. Bioorganic \& Medicinal Chemistry Letters 23(21), 5900-5903.

Fatmawati S, Kurashiki K, Takeno S, Kim YU, Shimizu K, Sato M, Imaizumi K, Takahashi K, Kamiya S, Kaneko S, Kondo R. 2009 - The inhibitory effect on aldose reductase by an extract of Ganoderma lucidum. Phytotherapy Research 23(1), 28-32.

Fatmawati S, Shimizu K, Kondo R. 2010a - Ganoderic acid Df, a new triterpenoid with aldose reductase inhibirory activity from the fruiting body of Ganoderma lucidum. Fitoterapia 81(8), 1033-1036.

Fatmawati S, Shimizu K, Kondo R. 2010b - Inhibition of aldose reductase in vitro by constituents of Ganoderma lucidum. Planta Medica 76(15), 1691-1693.

Fatmawati S, Shimizu K, Kondo R. 2011a - Ganoderol B: a potent alphaglucosidase inhibitor isolated from the fruiting body of Ganoderma lucidum. Phytomedicine 18(12), 1053-1055.

Fatmawati S, Shimizu K, Kondo R. 2011b - Structure-activity relationships of Ganoderma acids from Ganoderma lucidum as aldose reductase inhibitors. Bioorganic \& Medicinal Chemistry Letters 21(24), 7295-7297.

Feldhammer M, Uetani N, Miranda-Saavedra D, Tremblay ML. 2013 - PTP1B: a simple enzyme for a complex world. Critical Reviews in Biochemistry and Molecular Biology 48(5), 430 445.

Ferreira ICFR, Heleno SA, Reis FS, Stojkovic M, Queiroz MJ, Vasconcelos MH, Sokovic M. 2014 - Chemical features of Ganoderma polysaccharides with antioxidant, antitumor and antimicrobial activities. Phytochemistry 114, 38-55. doi: 10.1016/j.phytochem.2014.10.011

Fidelis QC, Ribeiro TA, Araújo MF, de Carvalho MG. 2014 - Ouratea genus: Chemical and pharmacological aspects. Revista Braseileira de Farmacognosia 24(1), 1-19.

Frost M. 2016 - Three Popular Medicinal Mushroom Supplements: A Review of Human Clinical Trials. All Faculty Publications 1609.

Fu HD, Wang ZY. 1982 - The clinical effects of Ganoderma lucidum spore preprations in 10 cases of atrophic myotonia. Journal of Traditional Chinese Medicine $=$ Chung $i$ tsa chih ying wen pan/sponsored by All-China Association of Traditional Chinese Medicine, Academy of Traditional Chinese Medicine 2(1), 63-65.

Futrakul N, Boongen M, Tosukhowong P, Patumraj S, Futrakul P. 2002 - Treatment with Vasodilators and Crude Extract of Ganoderma lucidum suppresses proteinuria in nephrosis with focal segmental glomerulosclerosis. Nephron 92(3), 719-720.

Gamo FJ, Sanz LM, Vidal J, de Cozar C, Alvarez E, Lavandera JL, Vanderwall DE, Green DV, Kumar V, Hasan S, Brown JR, Peishoff CE, Cardon LR, Garcia-Bustos JF. 2010 Thousands of chemical starting points for antimalarial lead identification. Nature 465, 305310.

Gao H, Chan E, Zhou F. 2004a - Immunomodulating activities of Ganoderma, a mushroom with medicinal properties. Food Reviews International 20, 123-161.

Gao H, Chan E, Zhou F. 2004b - Immunomodulating activities of Ganoderma, a mushroom with medicinal properties. Food Reviews International 20, 123-161. 
Gao P, Hirano T, Chen Z, Yasuhara T, Nakata Y, Sugimoto A. 2012 - Isolation and identification of C-19 fatty acids with anti-tumor activity from the spores of Ganoderma lucidum (reishi mushroom). Fitoterapia 83(3), 490-499.

Gao Y, Zhou S, Chen G, Dai X, Ye J, Gao H. 2002a - A phase I/II study of a Ganoderma lucidum (Curt. Fr.) P Karst. (Ling Zhi, Reishi mushroom) extract in patients with chronic hepatitis B. International Journal of Medicinal Mushrooms 4(4), 321-327.

Gao Y, Zhou S, Huang M, Xu A. 2003 - Antibacterial and antiviral value of the genus Ganoderma P. Karst. species (Aphyllophoromycetideae): A review. International Journal of Medicinal Mushrooms 5(3), 235-246.

Giavasis I 2014 - Polysaccharides from Medicinal Mushrooms for Potential use as Nutraceuticals. In: Benkeblia N (Ed.), Polysaccharides: Natural Fibers in Food and Nutrition, $1^{\text {st }}$ Edition, CRC Press 171-206. doi: 10.1201/b17121-9

Gill SK, Rieder MJ. 2008 - Toxicity of a traditional Chinese medicine, Ganoderma lucidum, in children with cancer. Canadian Journal of Clinical Pharmacology 15(2), 275-85. (Epub)

Goino T 2004 - Physiologically active compositions based upon active ingredients of Basidiomycotina and Araliaceae US6746675 B2.

Gonzalez AG, Leon F, Rivera A, Padron JI, Gonzalez-Plata J, Zuluaga JC, Quintana J, Estevez F, Bermejo J. 2002 - New lanostanoids from the fungus Ganoderma concinna. Journal of Natural Products 65(3), 417-421.

Hada H, Tokumoto W, Namba T. 1989 - Dental caries prevention by traditional medicines. XII. Effect of components of Ganoderma lucidum on glucosyltransferase from Streptococcus mutans. Journal of Medical and Pharmaceutical Society for WAKAN - YAKU 6, 100-107.

Hajjaj H, Mace C, Roberts M, Niederberger P, Fay LB. 2005 - Effect of 26-oxygenosterols from Ganoderma lucidium and their activity as cholesterol synthesis inhibitors. Applied and Environmental Microbiology 71(7), 3653-3658.

Hapuarachchi KK, Wen TC, Deng CY, Kang JC, Hyde KD. 2015 - Mycosphere Essays 1: Taxonomic confusion in the Ganoderma lucidum species complex. Mycosphere 6(5), 542559. doi: $10.5943 /$ mycosphere/6/5/4

Hapuarachchi KK, Wen TC, Jeewon R, Wu XL, Kang JC, Hyde KD. 2016 - Mycosphere Essays 7: Ganoderma lucidum - are the beneficial anti-cancer properties substantiated? Mycosphere 7(3), 305-332. doi: 10.5943/mycosphere/7/3/6

He Z, Naruse K, King GL. 2005 - Effects of diabetes and insulin resistance on endothelial functions. In: Johnstone M, Veves A. (Eds.), Diabetes and Cardiovascular Diseases. Humana Press 25-46.

Heleno SA, Ferreira IC, Esteves AP, Ćirić A, Glamočlija J, Martins A, Soković M, Queiroz MJ. 2013 - Antimicrobial and demelanizing activity of Ganoderma lucidum extract, $p$ hydroxybenzoic and cinnamic acids and their synthetic acetylated glucuronide methyl esters. Food and Chemical Toxicology 58, 95-100.

Hernandez-Marquez E, Lagunas-Martinez A, Bermudez-Morales VH, Burgete-Garcfa AI, LeonRivera I, Montiel-Arcos E, Garcia-Villa E, Gariglio P, Ondarza-Vidaurreta RN. 2014 Inhibitory activity of Lingzhi or Reishi medicinal mushroom, Ganoderma lucidum (Higher Basidiomycetes) on transformed cells by Human Papillomavirus. International Journal of Medicinal Mushrooms 16(2), 179-187.

Hijikata Y, Yamada S. 1998 - Effect of Ganoderma lucidum on postherpetic neuralgia. The American Journal of Chinese Medicine 26(03n04), 375-81.

Hijikata Y, Yasuhara A, Sahashi Y. 2005 - Effect of an herbal formula containing Ganoderma lucidum on reduction of herpes zoster pain: a pilot clinical trial. The American Journal of Chinese Medicine 33(4), 517-523.

Hikino H, Ishiyama M, Suzuki Y, Konno C. 1989 - Mechanisms of hypoglycemic activity of Ganoderic B: a glycan of Ganoderma lucidum fruit bodies. Planta Medica 55(5), 423-428.

Hikino H, Mizuno T.1985 - Hypoglycemic actions of some heteroglycans of Ganoderma lucidum fruit bodies. Planta Medica 55(4), 385. 
Hobbs C 1995 - Medicinal mushrooms: an exploration of tradition, healing \& culture. Santa Cruz, CA: Botanica Press 252.

Hsu PY, Chern JL, Chen HY, Yang SH. 2012 - Extract of sporoderm-broken germinating spores of Ganoderma lucidum activates human polymorphonuclear neutrophils via the P38 mitogenactivated protein kinase pathway. Chang Gung Medical Journal 35(2), 140-147.

$\mathrm{Hu}$ M, Zeng W, Tomlinson B. 2014 - Evaluation of a crataegus-based multiherb formula for dyslipidemia: a randomized, double-blind, placebo-controlled clinical trial. Evidence-Based Complementary and Alternative Medicine 365742. doi: 10.1155/2014/365742 (Epub)

Index Fungorum 2016: http://www.indexfungorum.org (accessed 01 February 2016).

Isaka M, Chinthanom P, Kongthong S, Srichomthong K, Choeklin R. 2013 - Lanostane triterpenes from cultures of the basidiomycete Ganoderma orbiforme BCC 22324. Phytochemistry 87, 133-139.

Jang SH, Yoon HM, Kim BH, Jang KJ, Kim CH. 2015 - Effect of Ganoderma lucidum Pharmacopuncture on Chronic Liver Injury in Rats. The Acupuncture 32(1), 13-22.

Jia J, Zhang X, Hu YS, Wu Y, Wang QZ, Li NN, Gui QC, Dong XC. 2009 - Evaluation of in vivo antioxidant activities of Ganoderma lucidum polysaccharides in STZ-diabetic rats. Food Chemistry 115(1), 32-36.

Jin H, Zhang G, Cao X. 1996 - Treatment of hypertension by Lingzhi combined with hypotensor and its effects on arterial, arteriolar and capillary pressure and microcirculation. In: Nimmi H, Xiu R.J, Sawada T, Zheng C. (Eds.). Microcirculatory Approach to Asian Traditional Medicine. New York, Elsevier Science.

Jonathan SG, Awotona FE. 2010 - Studies on Antimicrobial Potentials of three Ganoderma species. African Journal of Biomedical Research 13(2), 133-139.

Jun T, Ke-yan F. 1990 - Experimental and clinical studies on inhibitory effect of Ganoderma lucidum on platelet aggregation. Journal of Tongji Medical University 10(4), 240-243.

Kana Y, Chen T, Wu Y, Wu J. 2015 - Antioxidant activity of polysaccharide extracted from Ganoderma lucidum using response surface methodology. International Journal of Biological Macromolecules 72, 151-157.

Kanmatsuse K, Kajiwara N, Hayashi K, Shimogaichi S, Fukinbara I, Ishikawa H, Tamura T. 1985 - Studies on Ganoderma lucidium efficacy against hypertentsion and side effects. Yakugaku Zasshi - Journal of the Pharmaceutical Society of Japan 105(10), 942-947.

Kawagishi H, Mitsunaga SI, Yamawaki M, Ido M, Shimada A, Kinoshita T, Murata T, Usui T, Kimura A, Chiba S. 1997 - A lectin from mycelia of the fungus Ganoderma lucidum. Phytochemistry 44(1), 7-10.

Keypour S, Riahi H, Moradali MF, Rafati H. 2008 - Investigation of the antibacterial activity of a chloroform extract of Lingzhi or Reishi medicinal mushroom, Ganoderma lucidum (W. Curt.: Fr.) P. Karst. (Aphyllophoromycetideae) International Journal of Medicinal Mushrooms 10(4), 345-349.

Kim YS, Eo SK, Oh KW, Lee CK, Han SS. 2000 - Antiherpetic activities of acidic protein bound polysaccharide isolated from Ganoderma lucidum alone and in combinations with interferons. Journal of Ethnopharmacology 72(3), 451-458.

Kinge TR, Mih AM. 2011 - Secondary metabolites of oil palm isolates of Ganoderma zonatum Murill from Cameroon and their cytotoxicity against five human tumour cell lines. African Journal of Biotechnology 10(42), 8440-8447.

Kino K, Mizumoto K, Sone T, Yamaji T, Watanabe J, Yamashita A, Yamaoka K, Shimizu, K, Ko K, Tsunoo H. 1990 - An immunomodulating protein, Ling Zhi-8 (LZ-8) prevents insulitis in non-obese diabetic mice. Diabetologia 33(12), 713-718.

Kino K, Yamashita A, Yamaoka K, Watanabe J, Tanaka S, Ko K, Shimizu K, Tsunoo H. 1989 Isolation and characterization of a new immunomodulatory protein, Ling Zhi-8 (LZ-8), from Ganoderma lucidum. Journal of Biological Chemistry 264(1), 472-478.

Kohda H, Tokumoto W, Sakamoto K, Michiko F, Hirai Y, Yamasaki K, Komoda Y, Nakamura H, Ishihara S, Uchida M. 1985 - The biologically active constituents of Ganoderma lucidum 
(FR.) Karst. histamine release-inhibitory triterpenes. Chemical and Pharmaceutical Bulletin 33(4), 1367-1374.

Kozarski M, Klaus A, Nikšić M, Vrvić MM, Todorović N, Jakovljević D, Van Griensven LJ. 2012 - Antioxidative activities and chemical characterization of polysaccharide extracts from the widely used mushrooms Ganoderma applanatum, Ganoderma lucidum, Lentinus edodes and Trametes versicolor. Journal of Food Composition and Analysis 26(1), 144-153.

Kulangara C, Luedin S, Dietz O, Rusch S, Frank G, Mueller D, Moser M, Kajava AV, Corradin G, Beck HP, Felger I. 2012 - Cell biological characterization of the malaria vaccine candidate trophozoite exported protein 1. PLoS One 7(10), e46112.

Kwok Y, Ng KF, Li CC, Lam CC, Man RY. 2005 - A prospective, randomized, double-blind, placebo-controlled study of the platelet and global hemostatic effects of Ganoderma lucidum (Ling-Zhi) in healthy volunteers. Anesthesia \& Analgesia 101(2), 423-426. doi: 10.1213/01.ANE.0000155286.20467.28

Lai CS, Yu MS, Yuen WH, So KF, Zee SY, Chang RC. 2008 - Antagonizing beta amyloid peptide neurotoxicity of the anti-aging fungus Ganoderma lucidum. Brain Research 1190, 215-224.

Lai KN, Chan LY, Tang SC, Leung JC. 2006 - Ganoderma extract prevents albumin-induced oxidative damage and chemokines synthesis in cultured human proximal tubular epithelial cells. Nephrology Dialysis Transplantation 21(5), 1188-1197. (Epub)

Lai T, Gao Y, Zhou SF. 2004 - Global marketing of medicinal Ling Zhi mushroom Ganoderma lucidum (W.Curt:Fr.) Lloyd (Aphyllophoromycetideae) products and safety concerns. International Journal of Medicinal Mushrooms 6(2), 189-194.

Lee IS, Ahn BR, Choi JS, Hattori M, Min BS, Bae KH. 2011 - Selective cholinesterase inhibition by lanostane triterpenes from fruiting bodies of Ganoderma lucidum. Bioorganic \& Medicinal Chemistry Letters 21(21), 6603-6607.

Lee IS, Seo JJ, Kim JP, Kim HJ, Youn UJ, Lee JS, Jung HJ, Na MK, Hattori M, Min BS, Bae KH. 2010 - Lanostane triterpenes from the fruiting bodies of Ganoderma lucidum and their inhibitory effects on adipocyte differentiation in 3T3-L1 cells Journal of Natural Products 73(2), 172-176.

Lee JM, Kwon H, Jeong H, Lee JW, Lee SY, Baek SJ, Surh YJ. 2001 - Inhibition of lipid peroxidation and oxidative DNA damage by Ganoderma lucidum. Phytotherapy Research 15(3), 245-249.

Li C, Li Y, Sun HH. 2006 - New ganoderic acids, bioactive triterpenoid metabolites from the mushroom Ganoderma lucidum. Natural Product Research 20(11), 985-991.

Li EK, Tam LS, Wong CK, Li WC, Lam CWK, Wachtel-Galor S, Benzie IFF, Leung PC, Tomlinson B. 2007 - Safety and efficacy of Ganoderma lucidum (Lingzhi) and San miao San supplementation in patients with rheumatoid arthritis: A double-blind, randomized, placebo-controlled pilot trial. Rheumatoid Arthritis - Arthritis Care \& Research 57(7), 1143-1150. doi: 10.1002/art.22994

Li F, Zhang Y, Zhong Z. 2011 - Antihyperglycemic effect of Ganoderma lucidum polysaccharides on streptozotocin-induced diabetic mice. International Journal of Molecular Sciences 12(9), 6135-6145.

Li J, Zhang J, Chen H, Chen X, Lan J, Liu C. 2013 - Complete Mitochondrial Genome of the Medicinal Mushroom Ganoderma lucidum. PLoS ONE 8(8), e72038. doi: 10.1371/journal.pone.0072038

Liang CJ, Lee CW' Sung HC, Chen YH, Chiang YC, 'Hsu HY, Tseng YC, Li CY, Wang SH, Chen YL. 2014 - Ganoderma lucidum Polysaccharides Reduce Lipopolysaccharide-Induced Interleukin-1 $\beta$ Expression in Cultured Smooth Muscle Cells and in Thoracic Aortas in Mice Evidence-Based Complementary and Alternative Medicine 305149. doi: 10.1155/2014/305149. (Epub)

Liu B 1974 - The Chinese medical fungi. Shanxi People's Press, Taiyuan 1-196. (in Chinese).

Liu C, Yang N, Song Y, Wang L, Zi J, Zhang S, Dunkin D,' Busse P, Weir D, Tversky J,' Miller RL, Goldfarb J,' Zhan J, Li XM. 2015a - Ganoderic acid C1 isolated from the anti-asthma 
formula, ASHMITM suppresses TNF- $\alpha$ production by mouse macrophages and peripheral blood mononuclear cells from asthma patients. International Immunopharmacology 27(2), 224-231. doi: 10.1016/j.intimp.2015.05.018 (Epub).

Liu J, Kurashiki K, Shimizu K, Kondo R. 2006 - Structure-activity relationship for inhibition of $5 \alpha$-reductase by triterpenoids isolated from Ganoderma lucidum. Bioorganic \& Medicinal Chemistry 14(24), 8654-8660.

Liu J, Shimizu K, Konishi F. 2007 - Anti-androgenic activities of the triterpenoids fraction of Ganoderma lucidum. Food Chemistry 100(4), 1691-1696.

Liu J, Yang F, Ye LB, Yang XJ, Timani KA, Zheng Y, Wang YH. 2004 - Possible mode of action of antiherpetic activities of a proteoglycan isolated from the mycelia of Ganoderma lucidum in vitro. Journal of Ethnopharmacology 95(2), 265-272.

Liu W, Wang H, Pang X, Yao W, Gao X. 2010 - Characterization and antioxidant activity of two low-molecular-weight polysaccharides purified from fruiting bodies of Ganoderma lucidum. International Journal of Biological Macromolecules 46(4), 451-457.

Liu X, Yuan JP, Chung CK, Chen XJ. 2002 - Antitumor activity of the sporoderm-broken germinating spores of Ganoderma lucidum. Cancer Letters 182(2), 155-161.

Liu YH, Lin YS, Lin KL, Lu YL, Chen CH, Chien MY, Shang HF, Lin SY, Hou WC. 2015b Effects of hot-water extracts from Ganoderma lucidum residues and solid-state fermentation residues on prebiotic and immune-stimulatory activities in vitro and the powdered residues used as broiler feed additives in vivo. Botanical Studies, An International Journal 56, 17.

Luo J, Zhao YY, Lin ZB. 2002 - A new lanostane-type triterpene from the fruiting bodies of Ganoderma lucidum. Journal of Asian Natural Products Research 4(2), 129-134.

Ma HT, Hsieh JF, Chen ST. 2015 - Anti-diabetic effects of Ganoderma lucidum. Phytochemistry $114,109-113$.

Mao XL 1998 - Economic fungi of China, (in Chinese). Science Press, Beijing 1-762

Mau JL, Lin HC, Chen CC. 2001 - Non-volatile components of several medicinal mushrooms. Food Research International 34(6), 521-526.

Mau JL, Lin HC, Chen CC. 2002 - Antioxidant properties of several medicinal mushrooms. Journal of Agricultural and Food Chemistry 50(21), 6072-6077.

McCormack JG, Westergaard N, Kristiansen M, Brand CL, Lau J. 2001 - Pharmacological approaches to inhibit endogenous glucose production as a means of anti-diabetic therapy. Current Pharmaceutical Design 7(14), 1451-1474.

Mehta S 2014 - Studies on genetic variability and bioactive molecules production by Ganoderma species. Ph.D. Thesis, Shoolini University of Biotechnology and Management Sciences Bajhol, Solan (HP), India.

Mendis C, Jacobsen JL, Gamage-Mendis A, Bule E, Dgedge M, Thompson R, Cuamba N, Barreto J, Begtrup K, Sinden RE, Høgh B. 2000 - Anopheles arabiensis and An. funestus are equally important vectors of malaria in Matola coastal suburb of Maputo, southern Mozambique. Medical and Veterinary Entomology 14(2), 171-180.

Mizuno T 1995 - Bioactive biomolecules of mushrooms: food function and medicinal effect of mushroom fungi. Food Reviews International 11(1), 5-21.

Mizuno T, Wang G, Zhang J, Kawagishi H, Nishitoba T, Li J. 2003 - Reishi, Ganoderma lucidum and Ganoderma tsugae, bioactive substances and medicinal effects. Food Reviews International 11(1), 151-166.

Mizushina Y, Takahashi N, Hanashima L, Koshino H, Esumi Y, Uzawa J, Sugawara F, Sakaguchi K. 1999 - Lucidenic acid O and lactone, new terpene inhibitors of eukaryotic DNA polymerases from a basidiomycete, Ganoderma lucidum. Bioorganic \& Medicinal Chemistry 7(9), 2047-2052.

Mohan K, Padmanaban M, Uthayakumar V. 2015 - Isolation, Structural Characterization and Antioxidant activities of Polysaccharide from Ganoderma lucidum (Higher Basidiomycetes). American Journal of Biology and Life Sciences 3(5), 168-175. 
Nahata A 2013 - Ganoderma lucidum: A Potent Medicinal Mushroom with Numerous Health Benefits. Pharmaceutica Analytica Acta 4, e159. doi: 10.4172/2153-2435.

Nayak RN, Dixitraj PT, Nayak A, Bhat K. 2015 - Evaluation of anti-microbial activity of spore powder of Ganoderma lucidum on clinical isolates of Prevotella intermedia: A pilot study. Contemporary Clinical Dentistry 6(1), S248. doi: 10.4103/0976-237X.166834.

Nguyen VT, Tung NT, Cuong TD, Hung TM, Kim JA, Woo MH, Choi JS, Lee JH, Min BS. 2015 Cytotoxic and anti-angiogenic effects of lanostane triterpenoids from Ganoderma lucidum. Phytochemistry Letters 12, 69-74.

Nithya M, Ambikapathy V, Panneerselvam A. 2015 - In vivo Antioxidant and Enzymatic Activity of Ganoderma lucidum (Curt. Fr.) P. Karst. on Mammary Cells of DMBA Induced Sprague dawley Rats. International Journal of Current Microbiology and Applied Sciences 4(6), 6977.

Niu X, Qiu M, Li Z, Lu Y, Cao P, Zheng Q. 2004 - Two novel 3, 4-seco-trinorlanostane triterpenoids isolated from Ganoderma fornicatum. Tetrahedron Letters 45(14), 2989-2993.

Noguchi M, Kakuma T, Tomiyasu K, Konishi F, Kumamoto S, Kondo R, Matsuoka K. 2005 Phase I study of a methanol extract of Ganoderma lucidum, edible and medicinal mushroom, in men with mild symptoms of bladder outlet obstruction. Urology 66 (Suppl $3 \mathrm{~A}), 21$.

Noguchi M, Kakuma T, Tomiyasu K, Kurita Y, Kukihara H, Konishi F, Kumamoto S, Shimizu K, Kondo R, Matsuoka K. 2008a - Effect of an extract of Ganoderma lucidum in men with lower urinary tract symptoms: a doubleblind, placebo-controlled randomized and doseranging study. Asian Journal of Andrology 10(4), 651-658.

Noguchi M, Kakuma T, Tomiyasu K, Yamada A, Itoh, K, Konishi F, Kumamoto S, Shimizu K, Kondo R, Matsuoka K. 2008b - Randomized clinical trial of an ethanol extract of Ganoderma lucidum in men with lower urinary tract symptoms. Asian Journal of Andrology 10(5), 777-785.

Oei P. 2003 - Mushroom cultivation in: Appropriate technology for mushroom growers, CTA 3rd edition. Backhays pubishers, Leiden. The Netherlands, 1-7

Oh KW, Lee CK, Kim YS, Eo SK, Han SS. 2000 - Antiherpetic activities of acidic protein bound polysacchride isolated from Ganoderma lucidum alone and in combination with Acyclovir and Vidarabine. Journal of Ethnopharmacology 72(1), 221-227.

Ojiezeh TI, Eghafona N'O. 2015 - Humoral responses of broiler chickens challenged with NDV following supplemental treatment with extracts of Aloe vera, Alma millsoni, Ganoderma lucidum and Archachatina marginata. Central European Journal of Immunology 40(3), 300-6. doi: 10.5114/ceji.2015.54590. (Epub)

Oliver-Krasinski JM, Kasner MT, Yang J, Crutchlow MF, Rustgi AK, Kaestner KH, Stoffers DA. 2009 - The diabetes gene Pdx1 regulates the transcriptional network of pancreatic endocrine progenitor cells in mice. The Journal of Clinical Investigation 119(7), 18881898.

Pan D, Wang L, Hu B, Zhou P. 2014 - Structural characterization and bioactivity evaluation of an acidic proteoglycan extract from Ganoderma lucidum fruiting bodies for PTP1B inhibition and anti-diabetes. Biopolymers 101(6), 613-623.

Pan D, Zhang D, Wu J, Chen C, Xu Z, Yang H, Zhou P. 2013 - Antidiabetic, antihyperlipidemic and antioxidant activities of a novel proteoglycan from Ganoderma lucidum fruiting bodies on $\mathrm{db} / \mathrm{db}$ mice and the possible mechanism. PloS ONE 8(7), e68332.

Park JH, Jang KJ, Kim CH, Lee YH, Lee SJ, Kim BH, Yoon HY. 2014 - Ganoderma lucidum Pharmacopuncture for the Treatment of Acute Gastric Ulcers in Rats. Journal of Pharmacopuncture 17(3), 40-49.

Paterson RR 2006 - Ganoderma - a therapeutic fungal bio factory. Phytochemistry 67(18), 19852001. 
Pillai TG, Devi PU. 2013 - Mushroom beta glucan: Potential candidate for post irradiation protection. Mutation Research/ Genetic Tocnicology and Environmental Mutagenesis 751(2), 109-115.

Pillai TG, Nair CKK, Janardhanan KK. 2010 - Enhancement of repair of radiation induced DNA strand breaks in human cells by Ganoderma mushroom polysaccharides. Food Chemistry 119(3), 1040-1043.

Richter C, Wittstein K, Kirk MP, Stadler M. 2015 - An assessment of the taxonomy and chemotaxonomy of Ganoderma. Fungal Diversity 71(1). doi: 10.1007/s13225-014-0313-6

Schemmel KE, Padiyara RS, D'Souza JJ. 2010 - Aldose reductase inhibitors in the treatment of diabetic peripheral neuropathy: a review. Journal of Diabetes and its Complications 24(5), 354-360.

Seo HW, Hung TM, Na M, Jung HJ, Kim JC. 2009 - Steroids and triterpenes from the fruit bodies of Ganoderma lucidum and their anti-complement activity. Archives of Pharmacal Research 32(11), 1573-1579.

Seow SL, Naidu M, David P, Wong KH, Sabaratnam V. 2013 - Potentiation of neuritogenic activity of medicinal mushrooms in rat pheochromocytoma cells. BMC Complementary and Alternative Medicine 13(1), 157.

Seto SW, Lam TY, Tam HL, Au ALS, Chan SW, Wu JH, Yu PHF, Leung GPH, Ngai SM, Yeung JHK, Leung PS, Lee SMY, Kwan YW. 2009 - Novel hypoglycemic effects of Ganoderma lucidum water-extract in obese/diabetic $(+\mathrm{db} /+\mathrm{db})$ mice. Phytomedicine 16(5), 426-436.

Shah P, Modi HA, Shukla MD, Lahiri SK. 2014 - Preliminary phytochemical analysis and antibacterial activity of Ganoderma lucidum collected from Dang District of Gujarat, India. International Journal of Current Microbiology and Applied Sciences 3(3), 246-255.

Sheena N, Ajith TA, Mathew AT, Janardhanan KK. 2003 - Antibacterial activity of three macro fungi, Ganoderma lucidum, Navesporus floccosa and Phellinus rimosus occurring in South India. Pharmaceutical biology 41(8), 564-567.

Shen CY, Dai L, Shen BD, Zhou X, Bai JX, Xu H, Lv QY, Han J, Yuan HL. 2015 Nanostructured lipid carrier based topical gel of Ganoderma Triterpenoids for frostbite treatment. Chinese journal of natural medicines 13(6), 454-460 doi: 10.1016/S1875-5364, $15,30039-X$

Shiao MS 2003 - Natural products of the medicinal fungus Ganoderma lucidum: occurrence, biological activities, and pharmacological functions. The Chemical Record 3(3), 172-180.

Singh AB, Gupta SK, Pereira BM, Prakash D. 1995 - Sensitization to Ganoderma lucidum in patients with respiratory allergy in India. Clinical and Experimental Allergy 25(5), 440-447 doi: http://dx.doi.org/10.1111/j.1365-2222.1995.tb01075.

Singh N, Rajini PS. 2004 - Free radical scavenging activity of an aqueous extract of potato peel. Food Chemistry 85(4), 611-616.

Singh SK, Doshi A, Pancholy A, Pathak R. 2013 - Biodiversity in wood-decay macro-fungi associated with declining arid zone trees of India as revealed by nuclear rDNA analysis. European Journal of Plant Pathology 136(2), 373-382.

Sliva D, Sedlak M, Slivova V, Valachovicova T, Lloyd F, HO NW. 2003 - Biologic activity of spores and dried powder from Ganoderma lucidum for the inhibition of highly invasive human breast and prostate cancer cells. The Journal of Alternative and Complementary Medicine 9(4), 491-497.

Smiderle FR, Ruthes AC, Iacomini M. 2015 - Natural Polysaccharides from Mushrooms: Antinociceptive and Anti-inflammatory Properties. Bioactivity and Biotechnology 20512178.

Soo TS 1994 - The therapeutic value of Ganoderma lucidum. In: Buchanan PK, Hseu RS, Moncalvo JM, (eds). Ganoderma systematics, phytopathology and pharmacology. Proceedings of contributed symposium 59A, B; 5th International Mycological Congress; 1994 Aug 14-21; Vancouver. Place of publication unavailable: Publisher unavailable 105113. 
Sridhar S, Sivaprakasam E, Balakumar R, Kavitha D. 2011 - Evaluation of antibacterial and antifungal activity of Ganoderma lucidum(curtis) P. Karst fruit bodies extracts. World Journal of Science and Technology 1(6), 08-11.

Stamets P 2000 - Growing Gourmet and Medicinal Mushrooms. Third Edition. Berkeley, Toronto, Ten Speed Press.

Su CH, Lai MN, Chan MH. 1993 - Hepato-protective triterpenoids from Ganoderma tsugae Murrill. In: Chang S, Buswell JA, Chiu S. (Eds) Mushroom Biology and Mushroom Products, The Chinese University Press, Hong Kong, China 275-283.

Su CY, Shiao MS, Wang CT. 1999 - Differential effects of Ganoderma acids on the thromboxane A 2-signaling pathways in human platelets. Biochemical Pharmacology 58(4), 587-595.

Suay I, Arenal F, Asensio FJ, Basilio A, Cabello MA, Diez MT, García JB, Del Val AG, Gorrochategui J, Hernández P, Peláez F. 2000 - Screening of Basidiomycetes for antimicrobial activities. Antonie van Leeuwenhoek 78(2), 129-140.

Sudheesh NA, Ajith TA, Janardhanan KK. 2013 - Ganoderma lucidum ameliorate mitochondrial damage in isoproterenol-induced myocardial infarction in rats by enhancing the activities of TCA cycle enzymes and respiratory chain complexes. International journal of cardiology 165(1), 117-125. doi: 10.1007/s10522-008-9208-9. (Epub).

Talesa VN 2001 - Acetylcholinesterase in Alzheimer's disease. Mechanisms of Ageing and Development 122(16), 1961-1969.

Tang W, Gao Y, Chen G, Gao H, Dai X, Ye J, Chan E, Huang M, Zhou S. 2005 - A randomized, double-blind and placebo-controlled study of a Ganoderma lucidum polysaccharide extract in neurasthenia. Journal of Medicinal Food 8(1), 53-8.

Tarlo SM, Bell B, Srinivasan J, Dolovich J, Hargreave FE. 1979 - Human sensitization to Ganoderma antigen. Journal of Allergy and Clinical Immunology 64, 43-49.

Tasaka K, Akagi M, Miyoshi K, Mio M, Makino T. 1988a - Anti-allergic constituents in the culture medium of Ganoderma lucidum. (I). Inhibitory effect of oleic acid on histamine release. Agents and Actions 23, 153-156.

Tasaka K, Mio M, Izushi, K, Akagi M, Mkino T. 1988b - Anti-allergic constituents in the culture medium of Ganoderma lucidum. (II). The inhibitory effect of cyclooctasulfur on histamine release. Agents and Actions 23, 157-160.

Taylor M, Reide P. 1998 - Crash Course in Pharmacology. Mosby, London. ISBN-10: 0723431256 , ISBN-13, 978-0723431251.

Teng BS, Wang CD, Yang HJ, Wu JS, Zhang D, Zheng M, Fan ZH. 2011 - A protein tyrosine phosphatase 1B activity inhibitor from the fruiting bodies of Ganoderma lucidum (Fr.) Karst and its hypoglycemic potency on streptozotocin-induced type 2 diabetic mice. Journal of Agricultural and Food Chemistry 59(12), 6492-6500.

Teng BS, Wang CD, Zhang D, Wu JS, Pan D, Pan LF, Yang HJ, Zhou P. 2012 - Hypoglycemic effect and mechanism of a proteoglycan from Ganoderma lucidum on streptozotocininduced type 2 diabetic rats. European Review for Medical and Pharmacological Sciences $16,166-175$.

Thakur A, Rana M, Lakhanpal TN, Ahmad A, Khan MI. 2007 - Purification and characterization of lectin from fruiting body of Ganoderma lucidum: Lectin from Ganoderma lucidum. Biochimica et Biophysica Acta (BBA) - General subjects 1770(9), 1404-1412.

Thyagarajan-Sahu A, Lane B, Sliva D. 2011 - ReishiMax, mushroom based dietary supplement, inhibits adipocyte differentiation, stimulates glucose uptake and activates AMPK. BMC Complementary and Alternative Medicine 11, 74. doi: 10.1186/1472-6882-11-74

Tie L, Yang HQ, An Y, Liu SQ, Han J, Xu Y, Hu M, Li WD, Chen AF, Lin ZB, Li XJ. 2012 Ganoderma lucidum polysaccharide accelerates refractory wound healing by inhibition of mitochondrial oxidative stress in type 1 diabetes. Cell Physiology and Biochemistry 29(34), 583-94. doi: 10.1159/000338512. (Epub)

Ulbricht C, Isaac R, Milkin T, Poole E, Rusie E, Grimes Serrano J, Weissner W, Windsor R, Woods J. 2010 - An evidence-based systematic review of stevia by the Natural Standard 
Research Collaboration. Cardiovascular \& Hematological Agents in Medicinal Chemistry $8(2), 113-127$.

Wachtel-Galor S, Buswell JA, Tomlinson B, Benzie IFF. 2004 - Lingzhi Polyporus fungus. In: Herbal and Traditional Medicine: Molecular Aspects of Health. Marcel Dekker Inc, New York, USA 179-228.

Wadt NSY, Okamoto MK, Hi EM, Bach EE. 2015 - Chemical, toxicological, anti-inflammatory and antimicrobial evaluation of Ganoderma lucidum extracts. Emirates Journal of Food and Agriculture 27(7), 577-584.

Wanachiwanawin D, Piankijagum A, Chaiprasert A, Lertlaituan P, Tungtrongchitr A, Chinabutr P. 2006 - Ganoderma lucidum: a cause of pseudoparasitosis. Southeast Asian Journal of Tropical Medicine and Public Health 37(6), 1099-1102.

Wang F, Zhou Z, Ren X, Wang Y, Yang R, Luo J, Strappe P. 2015 - Effect of Ganoderma lucidum spores intervention on glucose and lipid metabolism gene expression profiles in type 2 diabetic rats. Lipids in Health and Disease 14(1), 49. doi 10.1186/s12944-015-0045-y

Wang H, Ng TB. 2006 - Ganodermin, an antifungal protein from fruiting bodies of the medicinal mushroom Ganoderma lucidum. Peptides 27(1), 27-30.

Wang XC, Xi RJ, Li Y, Wang DM, Yao YJ. 2012 - The species identity of the widely cultivated Ganoderma, 'G. lucidum' (Ling-zhi), in China. PLoS one 7(7), e40857.

Wanmuang H, Leopaircut J, Kositchaiwat C. 2007 - Fatal fulminant hepatitis associated with Ganoderma lucidum (Lingzhi) mushroom powder. Journal-Medical Association of Thailand 90(1), 179-81.

Wasser SP, Coates P, Blackman M, Cragg G, Levine M, Moss J, White J. 2005 - Reishi or Lingzhi (Ganoderma lucidum). In: Encyclopedia of Dietary Supplements. Marcel Dekker, New York, USA 603-622.

Wasser SP, Weis AL. 1997 - Reishi Mushroom (Ganoderma lucidum (Fr.) Karst). In: E Nevo (ED). Med Mushrooms. Peledfus, Haifa, Israel.

Wells TNC, Alonso PL, Gutteridge WE. 2009 - New medicines to improve control and contribute to the eradication of malaria. Nature Reviews Drug Discovery 8(11), 879-891.

Weng Y, Xiang L, Matsuura A, Zhang Y, Huang Q, Qi J. 2010 - Ganodermasides A and B, two novel anti-aging ergosterols from spores of a medicinal mushroom Ganoderma lucidum on yeast via UTH1 gene. Bioorganic \& Medicinal Chemistry 18(3), 999-1002.

Wicks SM, Tong R, Wang CZ, O'Connor M, Karrison T, Li S, Moss J, Yuan CS. 2007 - Safety and tolerability of Ganoderma lucidum in healthy subjects: a double-blind randomized placebocontrolled trial. The American Journal of Chinese Medicine 35(3), 407-414.

Wu GS, Guo JJ, Bao JL, Li XW. 2013 - Anti-cancer properties of triterpenoids isolated from Ganoderma lucidum - a review. Expert Opinion on Investigational Drugs 22(8), 981-992.

www.concordhealth.net/doctor-research/cd-4----research (accessed 22 February 2016).

www.mycologyresearch.com/pdf/articles/Martin_Powell.pdf (accessed 22 February 2016).

Xiao GL, Liu FY, Chen ZH. 2003 - Clinical observation on treatment of Russula subnigricans poisoning patients by Ganoderma lucidum decoction. Zhongguo Zhong xi yi jie he za zhi Zhongguo Zhongxiyi jiehe zazhi= Chinese journal of integrated traditional and Western medicine/Zhongguo Zhong xi yi jie he xue hui, Zhongguo Zhong yi yan jiu yuan zhu ban 23(4), 278-280.

Yang HB, Hui CC, Jang LT, Sun HL. 2013 - Bioconversion of Ginsenosides in the American Ginseng Extraction Residue by Fermentation with Lingzhi (Ganoderma lucidum). Journal of Traditional and Complementary Medicine 3(2), 95-101.

Yen GC, Wu JY. 1999 - Antioxidant and radical scavenging properties of extracts from Ganoderma tsugae. Food Chemistry 65(3), 375-379.

Ying J, Mao X, Ma Q, Wen H. 1987 - Icons of medicinal fungi from China, (in Chinese). Science, Beijing 151-155. 
Yoon SY, Eo SK, Kim YS, Lee CK, Han SS. 1994 - Antimicrobial activity of Ganoderma lucidum extract alone and in combination with some antibiotics. Archives of Pharmacal Research $17(16), 438-42$.

You YH, Lin ZB. 2002 - Protective effects of Ganoderma lucidum polysaccharides peptide on injury of macrophages induced by reactive oxygen species. Acta Pharmacologica Sinica 23 (9), 787-791.

Yuan JF, Zhang ZQ, Fan ZC, Yang JX. 2008 - Antioxidant effects and cytotoxicity of three purified polysaccharides from Ligusticum chuanxiong Hort. Carbohydrate Polymers 74, 822-827.

Yuen JW, Gohel MD. 2005 - Anti-cancer Effects of Ganoderma lucidum: A review of scientific evidence. Nutrition and Cancer 53(1), 11-17.

Zhang HN, He JH, Yuan L, Lin ZB. 2003 - In vitro and in vivo protective effect of Ganoderma lucidum polysaccharides on alloxan-induced pancreatic islets damage. Life sciences 73(18), 2307-2319.

Zhang S, Nie S, Huang D, Li W, Xie M. 2013 - Immunomodulatory effect of Ganoderma atrum polysaccharide on CT26 tumor-bearing mice. Food Chemistry 136(3), 1213-1219.

Zhang W, Zhang Q, Deng W, Li Y, Xing G, Shi X, Du Y. 2014 - Neuroprotective effect of pretreatment with Ganoderma lucidum in cerebral ischemia/reperfusion injury in rat hippocampus. Neural Regeneration Research 9(15), 1446-1452.

Zhang XQ, Ip FC, Zhang DM, Chen LX, Zhang W, Li YL, Ip NY, Ye WC. 2011 - Triterpenoids with neurotropic activity from Ganoderma lucidum. Natural Product Research 25(17), 1607-1613.

Zhang Y, Luo J, Huang NH, Zhang XY. 2012 - Influence of Ganoderma lucidum triterpenoids on learning memory function and ACh content in Alzheimer disease model rat. Chinese Journal of Experimental Traditional Medicine Formulae 16, 172-175.

Zhao HB, Lin SQ, Liu JH, Lin ZB. 2004 - Polysaccharide extract isolated from Ganoderma lucidum protects rat cerebral cortical neurons from hypoxia/reoxygenation injury. Journal of Pharmacological Sciences 95(2), 294-298.

Zhao S, Ye G, Fu G, Cheng JX, Yang BB, Peng C. 2011 - Ganoderma lucidum exerts anti-tumor effects on ovarian cancer cells and enhances their sensitivity to cisplatin. International Journal of Oncology 38, 1319-1327.

Zhao W, Jiang X, Deng W, Lai, Y, Wu M, Zhang Z. 2012 - Antioxidant activities of Ganoderma lucidum polysaccharides and their role on DNA damage in mice induced by cobalt-60 gamma-irradiation. Food and Chemical. Toxicology 50(2), 303-309.

Zhao XR, Huo XK, Dong PP, Wang C, Huang SS, Zhang BJ, Zhang HL, Deng S, Liu KX, Ma XC. 2015 - Inhibitory Effects of Highly Oxygenated Lanostane Derivatives from the Fungus Ganoderma lucidum on P-Glycoprotein and $\alpha$-Glucosidase. Journal of Natural Products 78(8), 1868-1876.

Zheng J, Yang B, Yu Y, Chen Q, Huang T, Li D. 2012 - Ganoderma lucidum polysaccharides exert anti-hyperglycemic effect on streptozotocin-induced diabetic rats through affecting beta-cells. Combinational Chemistry and High Throughput Screen 15(7), 542-550.

Zhou LW, Cao Y, Wu SH, Vlasák J, Li DW, Li MJ, Dai YC. 2015 -. Global diversity of the Ganoderma lucidum complex (Ganodermataceae, Polyporales) inferred from morphology and multilocus phylogeny. Phytochemistry 114, 7-15.

Zhou X, Lin J, Yin Y, Zhao J, Sun X, Tang K. 2007 - Ganodermataceae: natural products and their related pharmacological functions. The American Journal of Chinese Medicine. 35(4), 559574.

Zhou Y, Qu ZQ, Zeng YS, Lin YK, Li Y, Chung P, Wong R, Hägg U. 2012 - Neuroprotective effect of preadministration with Ganoderma lucidum spore on rat hippocampus. Experimental and Toxicologic Pathology 64(7), 673-680.

Zhu M, Chang Q, Wong LK, Chong FS, Li RC. 1999 - Triterpene antioxidants from Ganoderma lucidum. Phytotherapy Research 13(6), 529-531. 
Zhu XL, Chen AF, Lin ZB. 2007 - Ganoderma lucidum polysaccharides enhance the function of immunological effector cells in immunosuppressed mice. Journal of Ethnopharmacology 111(2), 219-26.

Ziegenbein FC, Hanssen HP, König WA. 2006 - Secondary metabolites from Ganoderma lucidum and Spongiporus leucomallellus. Phytochemistry 67(2), 202-211. 